\title{
Ablation of Glutamate Receptor GluR $\delta 2$ in Adult Purkinje Cells Causes Multiple Innervation of Climbing Fibers by Inducing Aberrant Invasion to Parallel Fiber Innervation Territory
}

\author{
Taisuke Miyazaki, ${ }^{1}$ Miwako Yamasaki, ${ }^{1}$ Tomonori Takeuchi, ${ }^{2,3}$ Kenji Sakimura, ${ }^{4,5}$ Masayoshi Mishina, ${ }^{2}$ \\ and Masahiko Watanabe ${ }^{1,5}$ \\ ${ }^{1}$ Department of Anatomy, Hokkaido University School of Medicine, Sapporo 060-8638, Japan, ${ }^{2}$ Department of Molecular Neurobiology and Pharmacology, \\ Graduate School of Medicine, University of Tokyo, Tokyo 113-0033, Japan, ${ }^{3}$ Laboratory for Cognitive Neuroscience, Centre for Cognitive and Neural \\ Systems, Division of Neuroscience, University of Edinburgh, Edinburgh EH8 9JZ, United Kingdom, ${ }^{4}$ Department of Cellular Neurobiology, Brain Research \\ Institute, Niigata University, Niigata 951-8585, Japan, and 5 Japan Science and Technology Agency, Core Research for Evolutional Science and Technology, \\ Sanbocho, Chiyada-ku, Tokyo 102-0075, Japan
}

Glutamate receptor GluR $\delta 2$ is exclusively expressed in Purkinje cells (PCs) from early development and plays key roles in parallel fiber (PF) synapse formation, elimination of surplus climbing fibers (CFs), long-term depression, motor coordination, and motor learning. To address its role in adulthood, we previously developed a mouse model of drug-induced GluR $\delta 2$ ablation in adult PCs (Takeuchi et al., 2005). In that study, we demonstrated an essential role to maintain the connectivity of PF-PC synapses, based on the observation that both mismatching of presynaptic and postsynaptic specializations and disconnection of PF-PC synapses are progressively increased after GluR $\delta 2$ ablation. Here, we pursued its role for CF wiring in adult cerebellum. In parallel with the disconnection of PF-PC synapses, ascending CF branches exhibited distal extension to innervate distal dendrites of the target and neighboring PCs. Furthermore, transverse $\mathrm{CF}$ branches, a short motile collateral rarely forming synapses in wild-type animals, displayed aberrant mediolateral extension to innervate distal dendrites of neighboring and remote PCs. Consequently, many PCs were wired by single main CF and other surplus CFs innervating a small part of distal dendrites. Electrophysiological recording further revealed that surplus CF-EPSCs characterized with slow rise time and small amplitude emerged after GluR $\delta 2$ ablation, and increased progressively both in number and amplitude. Therefore, GluR $\delta 2$ is essential for maintaining CF monoinnervation in adult cerebellum by suppressing aberrant invasion of CF branches to the territory of PF innervation. Thus, GluR $\delta 2$ fuels heterosynaptic competition and gives PFs the competitive advantages over CFs throughout the animal's life.

\section{Introduction}

Cerebellar Purkinje cells (PCs) receive two distinct excitatory afferents (Palay and Chan-Palay, 1974). Each PC receives $10^{5}-$ $10^{6}$ inputs from parallel fibers (PFs) at distal dendrites, whereas each PF forms one or two synapses to individual PCs (Napper and Harvey, 1988). In contrast, each PC is innervated by a single climbing fiber (CF) that originates from the inferior olive and forms hundreds of synapses by twisting around proximal dendrites. This PC circuitry is established through heterosynaptic competition between PFs and CFs and homosynaptic competition among multiple CFs (Mariani et al., 1977; Crepel, 1982;

Received Feb. 21, 2010; revised June 29, 2010; accepted Aug. 6, 2010.

This work was supported through Special Coordination Funds for Promoting Science and Technology, Grants-inAid for Scientific Research 19100005 (M.W.) and Grants-in-Aid for Scientific Research on Priority Area 17023001 (M.W.) provided by the Ministry of Education, Culture, Sports, Science and Technology of Japan.

Correspondence should be addressed to Masahiko Watanabe, Department of Anatomy, Hokkaido University School of Medicine, Sapporo 060-8638, Japan. E-mail: watamasa@med.hokudai.ac.jp.

DOI:10.1523/JNEUROSCI.0934-10.2010

Copyright $\odot 2010$ the authors $\quad 0270-6474 / 10 / 3015196-14 \$ 15.00 / 0$
Hashimoto et al., 2009). This competitive wiring is regulated by various signaling molecules expressed in cellular elements constituting PC synapses, including metabotropic glutamate receptor mGluR1, P/Q-type $\mathrm{Ca}^{2+}$ channels, glutamate receptor GluR $\delta 2$ (GluD2), and Cbln1 (or precerebellin) (Kano et al., 1995, 1997, 1998; Kashiwabuchi et al., 1995; Offermanns et al., 1997; Ichikawa et al., 2002; Miyazaki et al., 2004; Hirai et al., 2005).

Of these, GluR $\delta 2$ regulates heterosynaptic competition to the advantage of PF innervation (Watanabe, 2008; Yuzaki, 2009). GluR $\delta 2$ is dominantly expressed in PCs (Araki et al., 1993; Lomeli et al., 1993) and localized on spines contacting PFs (Takayama et al., 1995; Landsend et al., 1997). Targeted disruption of GluR $\delta 2$ gene in mice causes mismatching between presynaptic and postsynaptic specializations and disconnection at PF-PC synapses (Guastavino et al., 1990; Kashiwabuchi et al., 1995; Kurihara et al., 1997; Lalouette et al., 2001). The N-terminal domain of GluR $\delta 2$ has been demonstrated to mediate PF-PC synaptogenesis by interacting neurexin through Cbln1 (Uemura et al., 2007, 2010; Kakegawa et al., 2008, 2009; Uemura and 
Mishina, 2008; Torashima et al., 2009; Matsuda et al., 2010). The loss of GluR $\delta 2$ further affects CF innervation; CFs extend distally to take over free spines of the target and neighboring PCs, causing multiple CF innervation (Hashimoto et al., 2001; Ichikawa et al., 2002). Intriguingly, mutant mice lacking the $\mathrm{Ca}_{\mathrm{V}} 2.1$, a poreforming subunit of P/Q-type $\mathrm{Ca}^{2+}$ channels, display almost reciprocal phenotypes that PF territory expands, and CF territory regresses, down to PC somata and basal dendrites (Miyazaki et al., 2004). Therefore, the construction of functional PC circuits stands on competitive equilibrium among afferents promoted by distinct molecular mechanisms.

Heterosynaptic competition is still active in adult cerebellum, as surgical lesion to olivocerebellar projections or pharmacological blockade of cortical activities alters innervation territories of PFs and CFs reciprocally (Sotelo et al., 1975; Rossi et al., 1991a; Bravin et al., 1999; Cesa et al., 2005). To address the molecular mechanisms that maintain functional synaptic wiring in adult cerebellum, we previously developed a mouse model of CrePR/ loxP-mediated GluR $\delta 2$ ablation in adult PCs (Takeuchi et al., 2005). In that study, we demonstrated that GluR $\delta 2$ plays an essential role to maintain the connectivity of PF-PC synapses. Here, we addressed that GluR $\delta 2$ is also indispensable to maintain CF monoinnervation. After induction of GluR $\delta 2$ ablation, CF innervation extended distally and mediolaterally in the cerebellar cortex, giving rise to aberrant surplus branches that caused multiple innervation.

\section{Materials and Methods}

Animals. We used littermates derived from crossing of GluR $\delta 2^{\text {flox/flox }}$ and GluR $\delta 2^{\text {flox/CrePR }}$ mice on the pure C57BL/6 genetic background, as reported previously (Takeuchi et al., 2005). GluR $\delta 2^{\text {flox/CrePR }}$ mice were produced by crossing a target mouse line carrying the GluR $\delta 2$ gene flanked by loxP sequences with a Cre mouse line carrying the Cre recombinase-progesterone receptor (CrePR) fusion protein under the control of the GluR $\delta 2$ gene promoter. All animal experiments were performed according to the guidelines for the care and use of laboratory animals of the Hokkaido University School of Medicine. The GluR $\delta 2^{\text {flox }}$ allele was identified by PCR using primers $5^{\prime}$-AGCAACCTACACTCCCAAAGAAG-3' (FD2P3) and 5'-ATTCAGTGCCAAGACAGACAACAA-3' (FD2P4). The GluR $\delta 2^{\text {CrePR }}$ allele was identified by PCR using the $\mathrm{CreP} 1$ and CreP2 primers (Tsujita et al., 1999). For induction of PC-specific gene recombination, $11 \beta$-[ $p$-(dimethylamino)phenyl]-17 $\beta$-hydroxy-17(1-propynyl)estra-4,9-dien-3-one (RU-486) (Sigma-Aldrich), suspended at a concentration of $50 \mathrm{mg} / \mathrm{ml}$ in water containing $0.25 \%(\mathrm{v} / \mathrm{v})$ carboxymethyl cellulose and $0.5 \%(\mathrm{v} / \mathrm{v})$ Tween 80 , was injected intraperitoneally at a dose of $1 \mathrm{mg} / \mathrm{g}$ body weight RU-486 at postnatal day 42 (P42) to P45 for 2 consecutive days (Takeuchi et al., 2005). We also used global or null-type GluR $\delta 2-$ knock-out mice, which were produced as a Cre knock-in mouse line $\mathrm{D} 2 \mathrm{CreN}$ under the control of the GluR $\delta 2$ gene promoter (GluR $\delta 2^{\mathrm{Cre} / \mathrm{Cre}}$ ) using the C57BL/6 ES cell line RENKA (Mishina and Sakimura, 2007). Details of the GluR $\delta 2{ }^{\mathrm{Cre} / \mathrm{Cre}}$ mouse will be described elsewhere.

In each morphological analysis, we analyzed three GluR $\delta 2^{\text {flox/flox }}$ and three GluR $\delta 2^{\text {flox/CrePR }}$ as control and mutant mice, respectively. Under deep pentobarbital anesthesia, mice were perfused transcardially with $4 \%$ paraformaldehyde in $0.1 \mathrm{~m}$ sodium phosphate buffer, $\mathrm{pH}$ 7.2. After excision from the skull, brains were further immersed overnight in the same fixative and processed for preparation of parasagittal or horizontal microslicer sections (50 $\mu \mathrm{m}$ in thickness; VT1000S; Leica). When using parasagittal sections, analyses were done at the straight portion of the lobules IV-VI. For electrophysiological analysis, parasagittal cerebellar slices (250 $\mu \mathrm{m}$ in thickness) were prepared from three control and mutant mice at each time point after RU-486 administration, as described previously (Edwards et al., 1989; Yamasaki et al., 2006).

Immunofluorescence. We used goat calbindin antibody $(1 \mu \mathrm{g} / \mathrm{ml})$, guinea pig vesicular glutamate transporter VGluT2 antibody $(0.5 \mu \mathrm{g} / \mathrm{ml})$ and rabbit GluR $\delta 2$ antibody $(1 \mu \mathrm{g} / \mathrm{ml})$, the specificities of which have been reported previously (Araki et al., 1993; Miyazaki et al., 2003; Miura et al., 2006). For GluR $\delta 2$ immunofluorescence, sections were digested with $1 \mathrm{mg} / \mathrm{ml}$ pepsin (Dako) in PBS, pH 7.4/0.2 $\mathrm{N} \mathrm{HCl}$ for $3 \mathrm{~min}$ at $37^{\circ} \mathrm{C}$ in a water bath. All immunohistochemical incubations were done at room temperature in a free-floating state. For immunofluorescence, cerebellar sections were incubated with $10 \%$ normal donkey serum for 20 min, a mixture of primary antibodies overnight, and a mixture of Alexa Fluor 488-, indocarbocyanine (Cy3)-, and indodicarbocyanine (Cy5)labeled species-specific secondary antibodies for $2 \mathrm{~h}$ at a dilution of 1:200 (Invitrogen; Jackson ImmunoResearch). Images were taken with a confocal laser-scanning microscope (FV1000; Olympus) or with a fluorescence microscope (AX-70; Olympus) equipped with a digital camera (DP70; Olympus), and analyzed with MetaMorph software (Molecular Devices). The reach of CFs was evaluated by the distance from the base of the molecular layer to the tips of VGluT2-positive CF terminals relative to the total vertical height of the molecular layer.

Anterograde tracer labeling. Under anesthesia with chloral hydrate (350 $\mathrm{mg} / \mathrm{kg}$ body weight, i.p.), a glass pipette (G-1.2; Narishige) filled with 2-3 $\mu \mathrm{l}$ of $10 \%$ solution of biotinylated dextran amine (BDA) (3000 molecular weight; Invitrogen) or dextran Alexa 594 (DA-594) (Invitrogen) in PBS was inserted stereotaxically to the inferior olive by the dorsal approach. Tracers were injected by air pressure at 20 psi with 5 s intervals for $1 \mathrm{~min}$ (Pneumatic Picopump; World Precision Instruments). After $4 \mathrm{~d}$ of survival, mice were anesthetized and fixed by transcardial perfusion. For bright-field light microscopy, BDA-labeled CFs were visualized by overnight incubation with peroxidase-labeled streptavidin (Nichirei) and colored in black using 3,3'-diaminobenzidine (DAB) and cobalt. For combined labeling by tracer and immunofluorescence, DA-594-labeled microslicer sections were incubated with a mixture of calbindin and VGluT2 antibodies followed by incubation with fluorescent secondary antibodies for $2 \mathrm{~h}$. Images of double or triple labeling were taken with a confocal laser-scanning microscope. For quantitative analyses of transverse CF collaterals, six optical sections taken in the $z$-axis plane at an interval of $1 \mu \mathrm{m}$ were stacked into a single image, and $>15$ images were obtained from each mouse. We measured the number of transverse collateral branches originating from ascending CF branches; the incidence was calculated as the number per $100 \mu \mathrm{m}$ of the parent ascending branches. We counted the number of VGluT2-positive terminals per 100 $\mu \mathrm{m}$ of transverse branches. Quantitative analyses were performed with MetaMorph software, and all data were described as the mean \pm SEM. Statistical significance was evaluated by Mann-Whitney $U$ test. Statistical significance was assumed when $p<0.05$.

For immunoelectron microscopy, BDA-labeled microslicer sections were incubated with VGluT2 antibody diluted with Tris-buffered saline containing $1 \%$ bovine serum albumin and $0.004 \%$ saponin. Sections were then incubated with $1.4 \mathrm{~nm}$ gold particle-conjugated anti-guinea pig antibody (1:200; Nanogold; Nanoprobes) for $3 \mathrm{~h}$. Immunogold for VGluT2 was silver-enhanced with an HQ-silver enhance kit (Nanoprobes), whereas BDA was detected by overnight incubation with peroxidase-labeled streptavidin (Nichirei) and visualized with DAB. Sections were postfixed with $1 \%$ osmium tetroxide for $15 \mathrm{~min}$, dehydrated in graded alcohols, and embedded in Epon 812. Ultrathin sections (70 $\mathrm{nm}$ in thickness) were prepared with an ultramicrotome (Ultracut; Leica), and photographs were taken with an H-7100 electron microscope (Hitachi).

Electrophysiology. Whole-cell recordings were made from visually identified PCs using an upright microscope (BX51WI; Olympus) at $31^{\circ} \mathrm{C}$. Patch pipettes had resistance of $2-4 \mathrm{M} \Omega$ when filled with an internal solution composed of the following (in mM): $60 \mathrm{CsCl}, 10 \mathrm{Cs}$ D-gluconate, 20 TEA (tetraethylammonium)-Cl, 20 BAPTA, $4 \mathrm{MgCl}_{2}, 4$ ATP, 0.4 GTP, and 30 HEPES, pH 7.3, adjusted with CsOH. The pipette access resistance was compensated by $80 \%$. The composition of the standard bathing solution was as follows (in mM): $125 \mathrm{NaCl}, 2.5 \mathrm{KCl}, 2 \mathrm{CaCl}_{2}$, $1 \mathrm{MgSO}_{4}, 1.25 \mathrm{NaH}_{2} \mathrm{PO}_{4}, 26 \mathrm{NaHCO}_{3}$, and 20 glucose, bubbled with $95 \% \mathrm{O}_{2}$ and $5 \% \mathrm{CO}_{2}$. Bicuculline methochloride (10 $\mu \mathrm{M}$; Tocris Bioscience) was always added to the bath solution for blocking inhibitory synaptic transmission. Ionic currents were recorded with a patch-clamp amplifier (EPC10; HEKA). The signals were filtered at $2 \mathrm{kHz}$ and digitized at $20 \mathrm{kHz}$. On-line data acquisition and off-line data analysis were 
performed using PULSE software (HEKA). Stimulation pipettes (5-10 $\mu \mathrm{m}$ tip diameter) were filled with the standard saline and used to apply square pulses for focal stimulation (duration, $0.1 \mathrm{~ms}$; amplitude, 0-90 V). Decay time constant of CF-mediated EPSC (CF-EPSC) was measured by fitting the EPSC decay with single exponential (Llano et al., 1991). Passive membrane properties were calculated based on the equivalent circuit model proposed by Llano et al. (1991). The current in response to hyperpolarizing voltage steps from -70 to $-80 \mathrm{mV}$ was biphasic and fitted with two exponentials. Both time constants for the fast $(\tau 1)$ and slow $(\tau 2)$ components were not significantly different between control and mutant mice at any time points examined (supplemental Table S1, available at www.jneurosci.org as supplemental material). Statistical significance in frequency distribution was evaluated by $\chi^{2}$ test or Mann-Whitney $U$ test. Statistical significance was assumed when $p<0.05$. For linear regression analyses, Pearson's product moment correlation coefficient $\left(r^{2}\right)$ was calculated.

Rotarod test. Control $(n=15)$ and mutant $(n=11)$ mice were used for motor behavioral test at $8,12,16,20,24$, and 28 weeks after RU486 administration. Mice were housed individually and were handled for $\sim 1$ min a day for $7-10 \mathrm{~d}$ before behavioral tests. An animal was placed on the rod $(3.2 \mathrm{~cm}$ diameter) rotating at $15 \mathrm{rpm}$ (RRAC-3002; O'Hara), and given three trials with 45-60 min intertrial intervals. The latency to fall (retention time) was measured with cutoff time of $5 \mathrm{~min}$. Rotarod test was performed in a blind fashion. Statistical significance was evaluated by ANOVA with repeated measures followed by Student's $t$ test. Statistical significance was assumed when $p<0.05$.

\section{Results}

The global GluR $\delta 2$-knock-out mice display two major anatomical phenotypes in terms of CF-PC wiring: distal extension of CF territory and multiple CF innervation by surplus innervation to distal dendrites (Kashiwabuchi et al., 1995; Ichikawa et al., 2002). We first examined whether and how these phenotypes were reproduced after GluR $\delta 2$ ablation in the adulthood by anatomically investigating GluR $\delta 2^{\text {flox/flox }}$ (control) and GluR $\delta 2^{\text {flox/CrePR }}$ (mutant) mice at 2, 8, 16, and 24 weeks after RU-486 administration on 2 consecutive days during $\mathrm{P} 42-\mathrm{P} 45$ of age.

\section{Distal extension of CF innervation is induced after GluR 2 ablation}

Using parasagittal cerebellar sections, we applied double immunofluorescence for calbindin and VGluT2, markers for PCs and CF terminals, respectively (Fig. $1 A-D$ ). At all time points examined, CF terminals in control mice climbed up along proximal or shaft dendrites until their transition to distal dendrites or spiny branchlets (Fig. $1 A, E$ ), suggesting little influence, if any, on dendritic morphology and CF innervation by RU-486 administration per se. Reflecting the territorized innervation, CF terminals were distributed within basal four-fifths of the molecular layer in control mice.
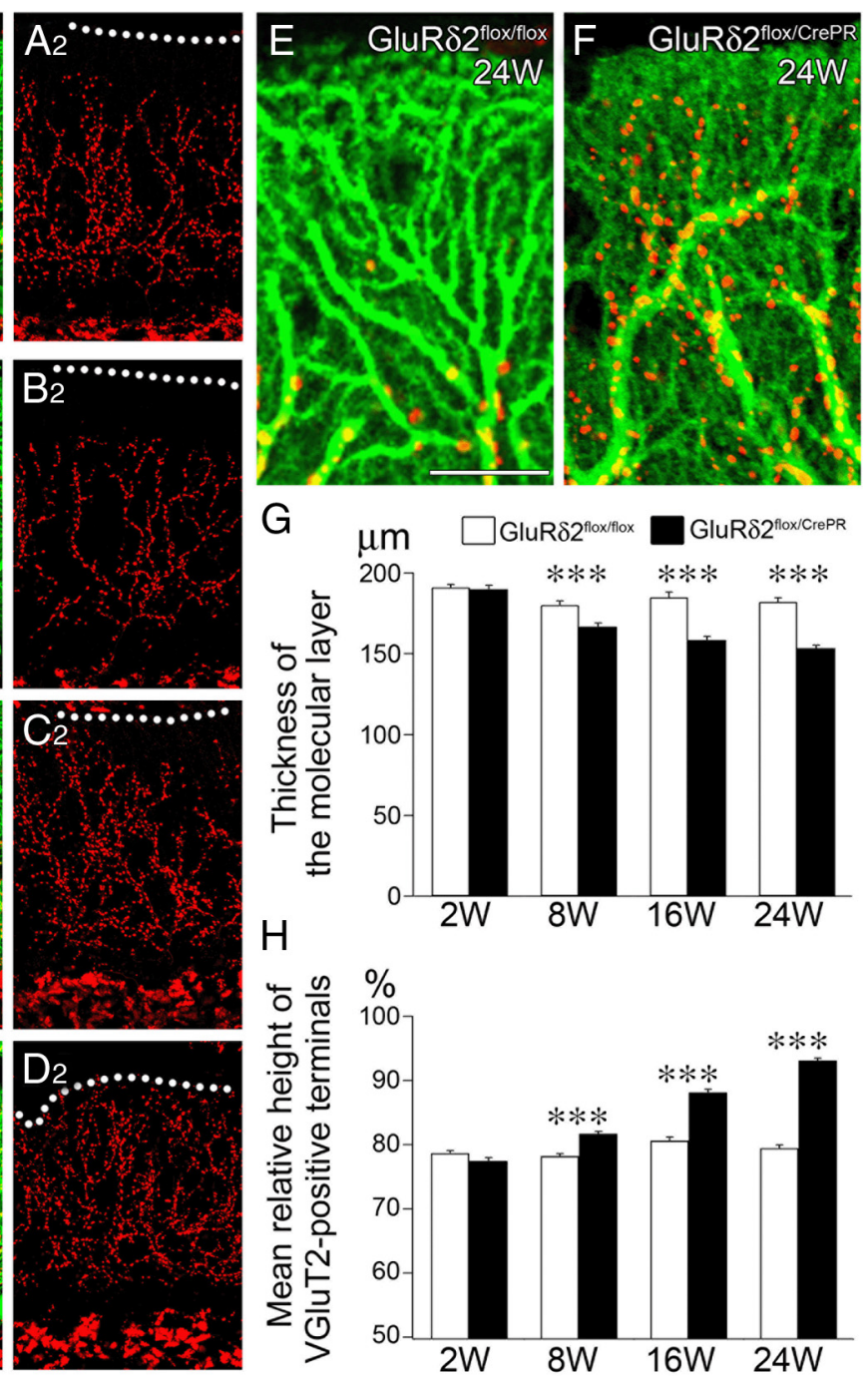

Figure 1. Progressive atrophy of the distal dendrites and molecular layer of $P C$ with reciprocal expansion of CF territory after induction of GluR $\delta 2$ ablation. $\boldsymbol{A}-\boldsymbol{F}$, Double immunofluorescence for calbindin (green) and vesicular glutamate transporter VGluT2 (red) in GluR $\delta 2^{\text {flox/flox }}$ at 2 weeks after RU-486 administration $(\boldsymbol{A})$ and GluR $\delta 2^{\text {flox/CrePR }}$ mice at 2 weeks $(\boldsymbol{B}), 8$ weeks $(\boldsymbol{C})$, and 24 weeks $(\boldsymbol{D})$ after RU-486 administration. $\boldsymbol{A}_{2}-\boldsymbol{D}_{2}$ are separated images of $\boldsymbol{A}_{\mathbf{1}}-\boldsymbol{D}_{1}$, respectively. Note atrophied distal dendrites of PCs and aberrant distal extension of CF innervation in GluR $\delta 2^{\text {flox/CrePR }}$ mice at 24 weeks after RU-486 administration $(\boldsymbol{F})$, compared with normal territorized innervation in GluR $\delta 2^{\text {flox/flox }}$ mice $(\boldsymbol{E}) . \mathbf{G}$, Changes in the thickness of the molecular layer after RU-486 and 181.9 $\pm 2.7(n=27)$ in GluR $\delta 2^{\text {flox/flox }}$ mice, and 189.9 $\pm 2.3(n=47), 166.6 \pm 2.3(n=49), 158.5 \pm 2.2(n=44)$, $53.4 \pm 1.8(n=31)$ in GluR $\delta 2^{\text {flox/CrePR }}$ mice at $2,8,16$, and 24 weeks after RU-486 administration, respectively (mean \pm SEM F terminals relative to the thickness of the molecular layer. Scores (in percentage) are $78.7 \pm 0.4$ ( $n=49$ sites), $78.2 \pm 0.4$ ( $n=$ , 80.6 $\pm 0.6(n=29)$, and 79.4 $\pm 0.5(n=27)$ in GluR $\delta 2^{\text {flox/flox }}$ mice, and 77.5 $\pm 0.5(n=43), 81.7 \pm 0.4(n=52), 88.1 \pm$ $0.5(n=44)$, and $93.1 \pm 0.3(n=31)$ in GluR $\delta 2^{\text {flox/CrePR }}$ mice at $2,8,16$, and 24 weeks after RU-486 administration, respectively (mean \pm SEM; $p=0.0979$ at 2 weeks; $p<0.00001$ at 8,16 , and 24 weeks, $U$ test). ${ }^{* *} p<0.001$. Scale bars: $\boldsymbol{A}-\boldsymbol{E}, 20 \mu \mathrm{m}$.

In mutant mice at 2 weeks after RU-486 administration, the distribution of CF terminals was comparable with that in control mice (Fig. $1 B$ ). At later time points, however, CF terminals were distributed closer to the pial surface (Fig. 1C,D). At high magnifications, distal dendrites of mutant PCs were stunted and studded with shrunken spines (Fig. $1 F$ ). Furthermore, CF terminals in mutant mice were not confined to proximal shaft dendrites, but also associated with the atrophied distal dendrites (Fig. $1 F$ ). These phenotypic alterations were confirmed by measuring the thickness of the molecular layer (Fig. 1G) and the height of VGluT2-positive CF terminals (Fig. $1 H$ ). The mean thickness of 

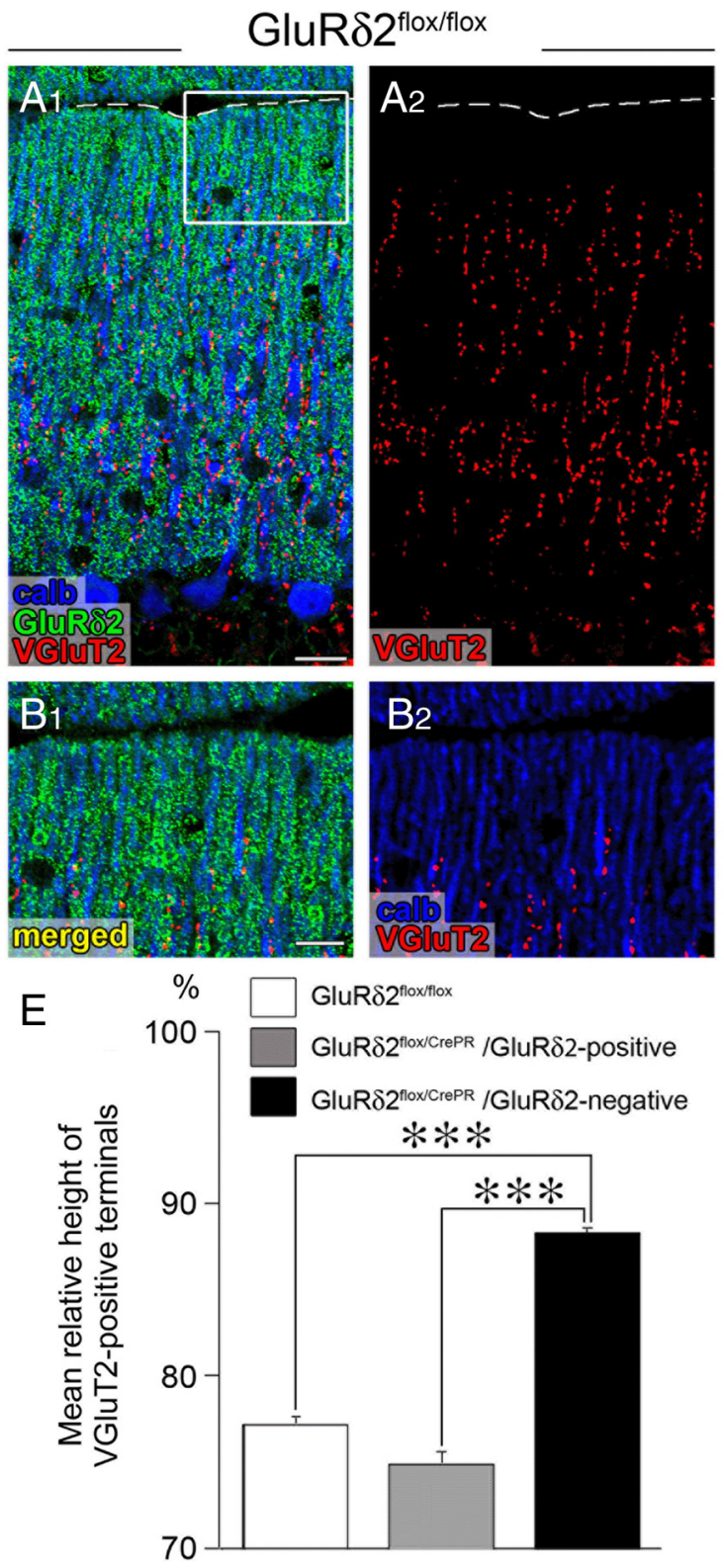
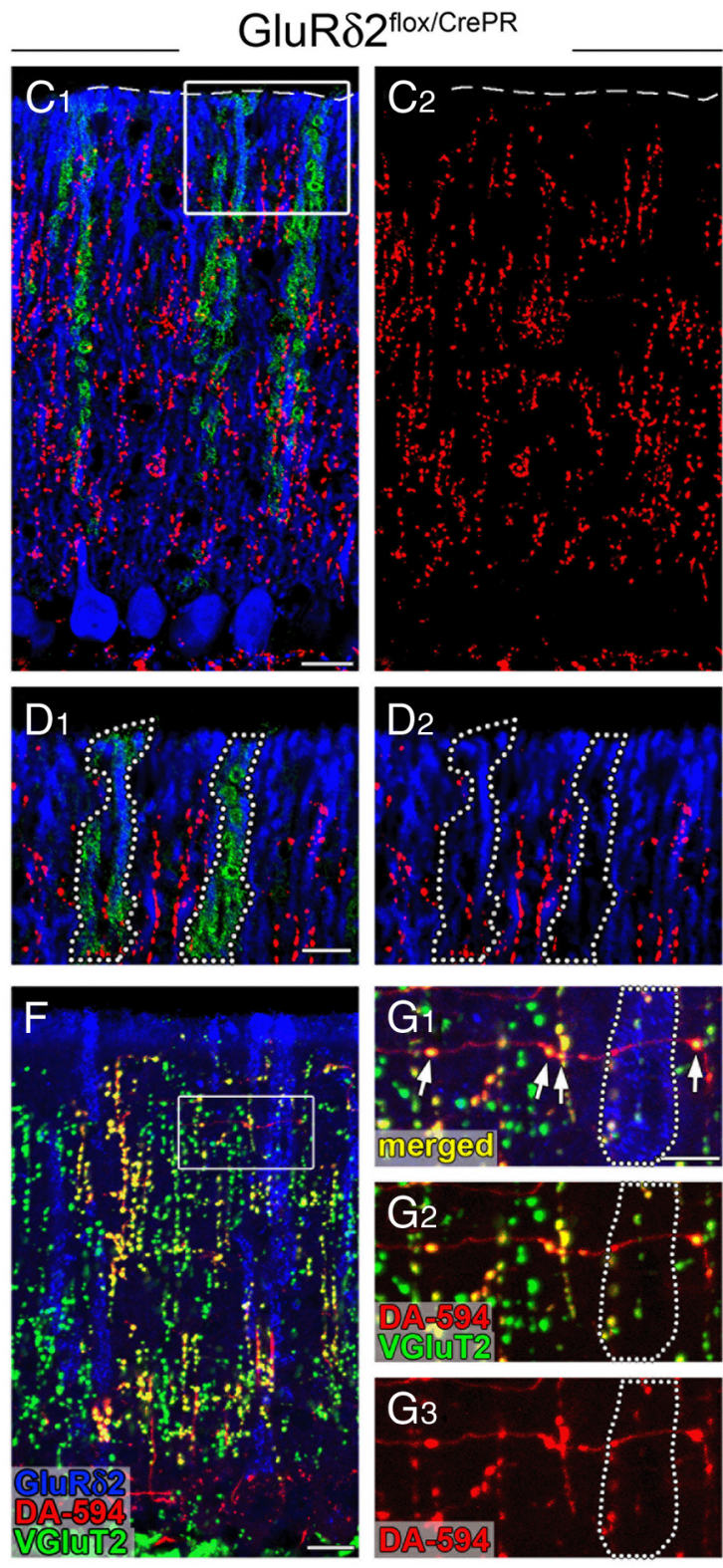

Figure 2. Aberrant extension and innervation of CFs along and against GluR $\delta 2$-negative $P\left(\right.$ dendrites. All data were obtained using horizontal cerebellar sections of in $G$ luR $\delta 2^{\text {flox/flox }}(A, B)$ and GluR $\delta 2^{\text {flox/CrePR }}(\boldsymbol{C}, \boldsymbol{D}, \boldsymbol{F}, \boldsymbol{G})$ mice at 12 weeks after RU-486 administration. The boxed regions in $\boldsymbol{A}, \boldsymbol{C}$, and $\boldsymbol{F}$ are enlarged in $\boldsymbol{B}, \boldsymbol{D}$, and $\mathbf{G}$, respectively. $\boldsymbol{A}-\boldsymbol{D}$, Triple immunofluorescence for calbindin (blue), GluR $\delta 2$ (green), and VGluT2 (red). Note that the reach of VGluT2-positive CF terminals selectively extends along GluR $\delta 2$-lacking dendrites, compared with that along GluR $\delta 2$-positive dendrites (encircled by dotted lines in $\boldsymbol{D}$ ). The broken lines in $\boldsymbol{A}$ and $\boldsymbol{C}$ indicate the pial surface. $\boldsymbol{E}$, A histogram showing the mean height to the tips of VGluT2-positive CF terminals relative to the height of the molecular layer. White bar, GluR $\delta 2^{\text {flox/flox }}$ mice; gray bar, GluR $\delta 2^{\text {flox/CrePR }}$ mice (along GluR $\delta 2$-positive dendrites); black bar, GluR $\delta 2{ }^{\text {flox/crePR }}$ mice (along GluR $\delta 2$-negative dendrites). Error bars indicate SEM. F, G, Triple fluorescent labeling for GluR $\delta 2$ (blue), anterograde tracer DA-594 (red), and VGluT2 (green). Note that VGluT2-positive terminals are preferentially differentiated where transverse $\left(F\right.$ branches cross with GluR $\delta 2$-negative dendrites, whereas such terminal differentiation is rarely found around GluR $\delta 2$-positive dendrites (encircled by dotted lines in $G$ ). ${ }^{* * *} p<$ 0.001. Scale bars: $A_{1}, C_{1}, F, 20 \mu \mathrm{m} ; B_{1}, D_{1}, G_{1}, 10 \mu \mathrm{m}$.

the molecular layer decreased progressively (Fig. 1G), whereas the mean relative height of $\mathrm{CF}$ terminals in molecular layer increased progressively (Fig. $1 H$ ), both showing significant differences at 8,16 , and 24 weeks ( $p<0.00001$ for each comparison, $U$ test). These results suggest that, after induction of GluR $\delta 2$ ablation, CF territory extends distally along atrophied distal dendrites.

After RU-486 administration, the ablation of GluR $\delta 2$ protein in mutant mice proceeds unevenly among PC populations (Takeuchi et al., 2005). We examined the relationship between distal extension of CF territory and GluR $\delta 2$ ablation by triple immunofluorescence for calbindin (blue), VGluT2 (red), and GluRס2 (green) at 12 weeks after RU-486 administration (Fig. 2A-
$E)$. In this analysis, we used horizontal cerebellar sections, in which PC dendrites are seen as single straight bars and GluR $\delta 2$ is detected, if expressed, on the surface of dendritic bars. In control mice, the reach of VGluT2-positive CF terminals up to basal four-fifths of the molecular layer was confirmed in horizontal sections (mean \pm SEM, $77.2 \pm 0.5 \%$ of the molecular layer; $n=$ 54) (Fig. $2 A, B, E$ ). In mutant mice, the relative reach was significantly extended along dendritic bars lacking GluR $\delta 2$ (88.2 \pm $0.4 \% ; n=38)$, compared with that along dendritic bars retaining GluR $\delta 2$ (75.2 $\pm 0.8 \% ; n=38 ; p<0.00001, U$ test) (Fig. $2 C-E$ ). Thus, distal extension of CF innervation selectively occurs along GluR $\delta 2$-ablated PC dendrites. 
GluR $\delta 2$ ablation induces multiple innervation by ascending $\mathrm{CF}$ branches Then we tested whether the distally extended ascending branches caused multiple innervation. To this end, we applied triple fluorescent labeling for calbindin (blue), VGluT2 (green), and anterograde tracer DA-594 (red) to distinguish anatomical forms of CF innervation (Fig. 3). In this analysis, $\mathrm{PC}$ dendrites that were associated with CF terminals either doublelabeled for DA594 and VGluT2 or singlelabeled for VGluT2 only were judged to be monoinnervated (supplemental Fig. S1 A, available at www.jneurosci.org as supplemental material), whereas those associated with double- and single-labeled CF terminals simultaneously were to be multiply innervated (supplemental Fig. S1 $B$, available at www.jneurosci.org as supplemental material).

In parasagittal cerebellar sections, monoinnervation pattern was overwhelming in control mice at each time point examined (Fig. $3 A$ ) and in mutant mice at 2 weeks after RU-486 administration (Fig. 3B). At 8 weeks and thereafter, mutant mice frequently displayed anatomical patterns of multiple innervation (Fig. 3C,D). For example, PC dendrites, marked as PCD-a, were mainly innervated by ascending branches of tracerlabeled CF-a (Fig. 3C) or tracer-unlabeled CF-a (Fig. 3D), respectively. These dendrites received additional innervation by tracer-unlabeled CF-b (Fig. 3C, green arrows) or tracer-labeled CF-b (Fig. 3D, red arrows), respectively, thus demonstrating the innervation by multiple CFs. Predominant monoinnervation in control mice and predominant multiple innervation in mutant mice were also confirmed using horizontal cerebellar sections at 16 weeks after RU-486 administration (supplemental Fig. S2, available at www.jneurosci.org as supplemental material). In particular, alternate innervation of single dendritic bars by tracer-labeled CF-a and tracer-unlabeled CF-b was readily captured in mutant mice (supplemental Fig. S2C, D, available at www. jneurosci.org as supplemental material). In general, terminals of additional CFs were few in number and intermingled with those formed by main CFs at 8 weeks (Fig.

$3 C$ ), whereas additional CFs often covered significant portions of PC dendrites and tended to be segregated from main CFs within the same dendrites at 16 and 24 weeks after RU-486 administration (Fig. $3 D$; supplemental Fig. S2C,D, available at www.jneurosci.org as supplemental material). Thus, the ablation of GluR $\delta 2$ induces aberrant wiring of ascending CF branches to dendrites of nearby PCs, thereby causes multiple innervation, and this is exacerbated with time after RU-486 administration.
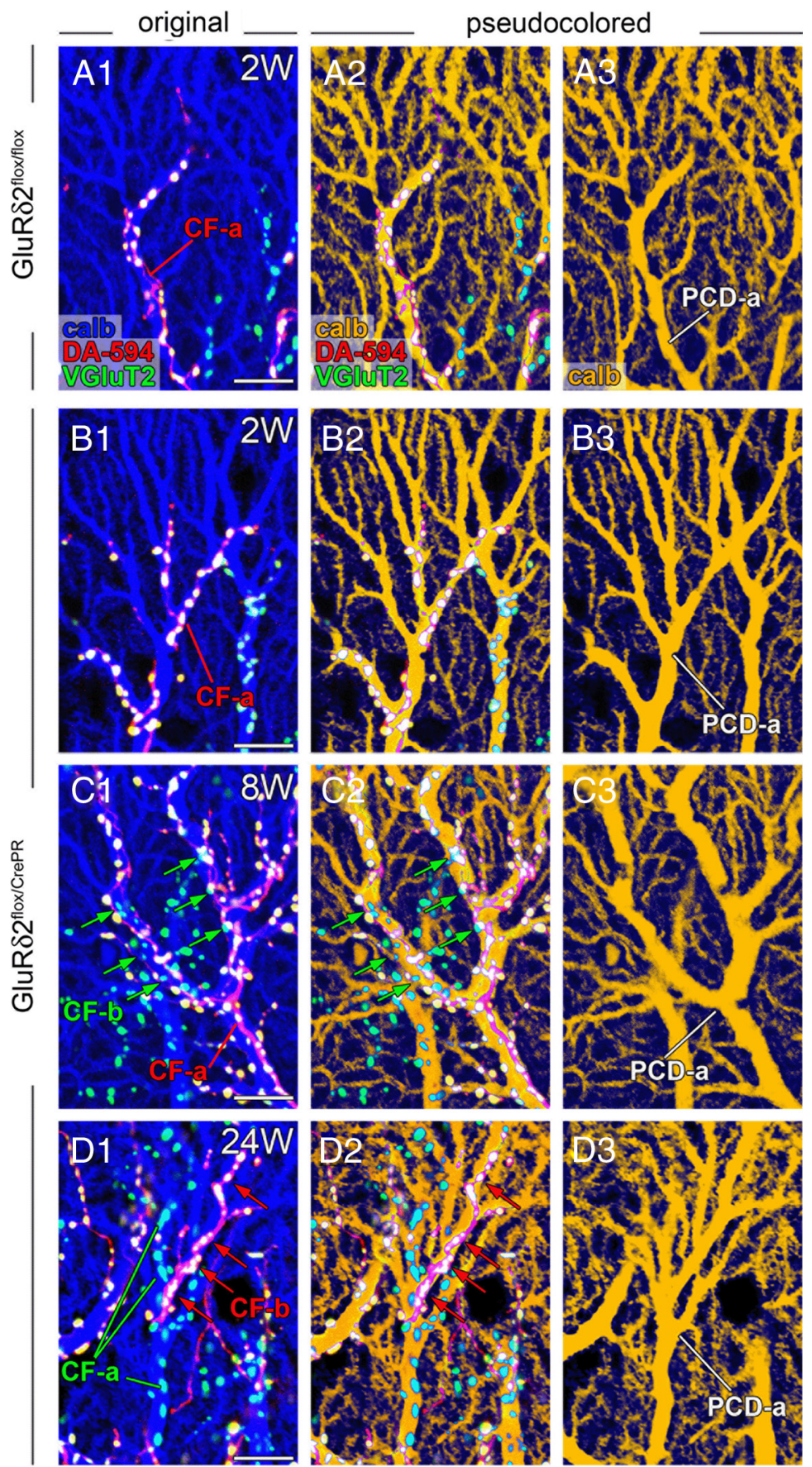

Figure 3. Multiple (F innervation by ascending CF branches after induction of GluR $\delta 2$ ablation. Each panel shows parasagittal cerebellar sections subjected to dextran Alexa-594 tracer labeling for CFs (DA-594; red) and immunofluorescence for calbindin (calb; blue) and VGluT2 (green) in GluR $\delta 2^{\text {flox/flox }}$ at 2 weeks after RU-486 administration $(\boldsymbol{A})$ and GluR $\delta 2^{\text {flox/CrePR }}$ mice at 2 weeks $(\boldsymbol{B}), 8$ weeks $(\boldsymbol{C})$, and 24 weeks $(\boldsymbol{D})$ after RU-486 administration. Immunoreaction for calbindin is pseudocolored in blue $\left(\boldsymbol{A}_{\mathbf{1}}-\boldsymbol{D}_{\boldsymbol{1}}\right)$ or brown $\left(A_{2}-D_{2}, A_{3}-D_{3}\right)$. CF-a indicates the CF mainly innervating a PC dendrite of interest (PCD-a). In GluR $\delta 2^{\text {flox/CrePR }}$ mice at 8 and 24 weeks, PCD-a is multiply innervated by both main (F-a and additional CF-b (arrows). Scale bars, $10 \mu \mathrm{m}$.

Aberrant mediolateral elongation and terminal differentiation of transverse $\mathrm{CF}$ branches

We also examined the transverse branch of CFs. This branch is a thin motile collateral, which originates from the parental ascending branches, extends mediolaterally in the horizontal and transverse cerebellar planes, and rarely forms conventional synapses in wild-type rodents (Rossi et al., 1991a; Sugihara et al., 1999; Nishiyama et al., 2007). In horizontal cerebellar sections, anterograde tracer BDA clearly visualized vertical ladders of ascending CF 

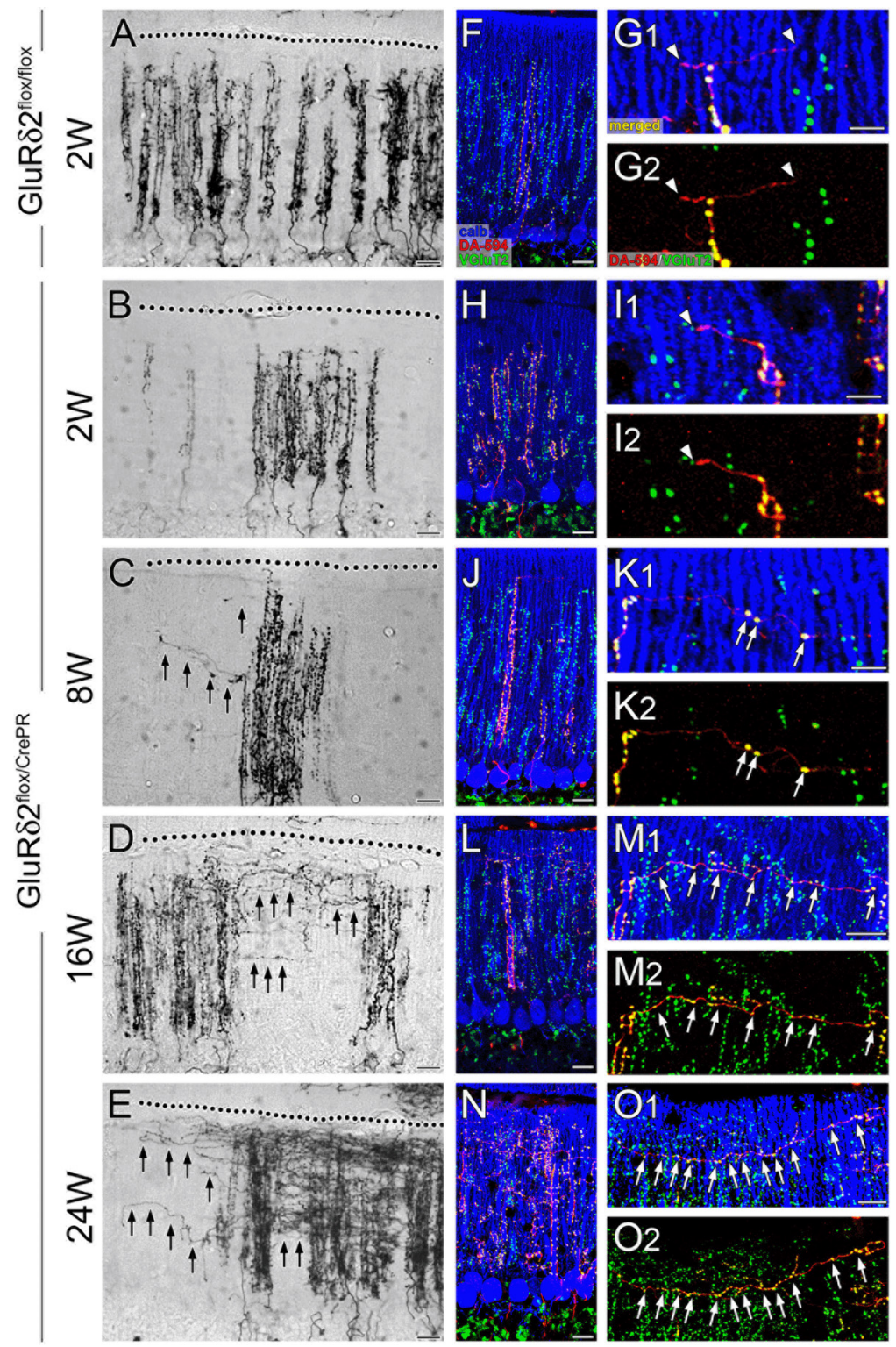

Figure 4. Progressive elongation and terminal differentiation of transverse CF branches after induction of GluR $\delta 2$ ablation. Anterograde tracer labeling of (Fs with BDA $(\boldsymbol{A}-\boldsymbol{E})$ and triple fluorescent labeling for anterograde tracer DA-594 (red), calbindin (blue), and VGluT2 (green) $(\boldsymbol{F}-\mathbf{0})$ in horizontal cerebellar sections of GluR $\delta 2^{\text {flox/flox }}$ at 2 weeks after RU-486 administration $(\boldsymbol{A}, \boldsymbol{F}$, $\boldsymbol{G})$ and of $\operatorname{GluR} \delta 2^{\text {flox/CrePR }}$ mice at 2 weeks $(\boldsymbol{B}, \boldsymbol{H}, \boldsymbol{I}), 8$ weeks $(\boldsymbol{C}, \boldsymbol{J}, \boldsymbol{K}), 16$ weeks $(\boldsymbol{D}, \boldsymbol{L}, \boldsymbol{M})$, and 24 weeks $(\boldsymbol{E}, \boldsymbol{N}, \boldsymbol{0})$ after RU-486 administration. In both types of mice, ascending (F branches are thick and beaded, and climb up vertically toward the pial surface (dotted line). Note progressive elongation of thin transverse branches of CFs in GluR $\delta 2^{\text {flox/CrePR }}$ mice (C-E, black arrows). The white arrowheads $(\boldsymbol{G}, \boldsymbol{I})$ and white arrows $(\boldsymbol{K}, \boldsymbol{M}, \mathbf{0})$ indicate terminal-like swellings that are VGluT2 negative or positive, respectively, to VGluT2. Scale bars: $\boldsymbol{A}-\boldsymbol{F}, \boldsymbol{H}, \boldsymbol{J}, \boldsymbol{L}, \boldsymbol{N}, 20 \mu \mathrm{m} ; \boldsymbol{G}, \boldsymbol{I}, \boldsymbol{K}, \boldsymbol{M}, \mathbf{0}, 10 \mu \mathrm{m}$. mice, transverse branches were immunonegative to VGluT2 at 2 weeks (Fig. $4 H, I$, arrowheads), but differentiated a few VGluT2-positive terminals at 8 weeks (Fig. $4 J, K$, arrows). These ectopic terminals were formed more around dendritic bars lacking GluR $\delta 2$ (6.1 \pm 0.6 per 100 $\mu \mathrm{m}$ of transverse branches; $n=29)$ than around those retaining GluR $\delta 2(2.6 \pm 0.7$; $n=31 ; p<0.00001, U$ test) (Fig. $2 F, G$ ), indicating that terminal differentiation on transverse branches was preferentially induced at around GluR $\delta 2$-ablated PC dendrites. In parallel with marked elongation of transverse branches, VGluT2-positive terminals were greatly increased in number at 16 and 24 weeks (Fig. $4 L-O$, arrows).

Indeed, the mean number of VGluT2positive terminals per $100 \mu \mathrm{m}$ of transverse branches increased strikingly from 8 weeks to 16 and 24 weeks, showing significant differences between control and mutant mice at 8 weeks $(p<0.01, U$ test) and at 16 and 24 weeks $(p<$ 0.00001 for each) (Fig. 5A). We also measured the mean number of transverse branches per $100 \mu \mathrm{m}$ of ascending branches, and found significant increase in mutant mice at 24 weeks after RU-486 administration (Fig. 5B) $(p<0.00001)$. Then, we plotted the number of VGluT2positive terminals on a given transverse branch against its relative vertical height in the molecular layer (Fig. $5 C-F$ ). In both types of mice, the majority of transverse branches originated and ran in the superficial one-half of the molecular layer [ control mice, $74.5 \%$ (143 of 192 branches) and $76.7 \%$ (145 of 189 branches) at 8 and 24 weeks, respectively; mutant mice, $70.0 \%$ (147 of 210 branches) and $70.4 \%$ (162 of 230 branches) at 8 and 24 weeks, respectively]. Therefore, GluR $\delta 2$ ablation has induced marked mediolateral elongation and extensive terminal differentiation in transverse CF branches, particularly, at the superficial molecular layer. branches in both types of mice (Fig. $4 A-E$ ). In such middle-power magnification of bright-field images, transverse branches were too short and thin to be identified at all time points in control mice and at 2 weeks in mutant mice (Fig. $4 A, B$ ). By contrast, a few transverse branches were clearly discerned to elongate in mutant mice at 8 weeks (Fig. 4C, arrows). At 16 and 24 weeks, transverse branches were further increased in number and length, particularly, in the superficial half of the molecular layer (Fig. 4D, E, arrows).

Morphological changes of transverse branches were examined more in detail by triple fluorescent labeling (Fig. $4 \mathrm{~F}-\mathrm{O}$ ). In control mice, DA-594-labeled transverse branches were uniformly thin in caliber and rarely formed VGluT2-positive terminals at each time point examined (Fig. $4 F, G$, arrowheads). In mutant

\section{Multiple CF innervation is also caused by transverse CF branches}

Whether the aberrant transformation of transverse branches also caused multiple innervation was examined using mutant mice at 16 weeks after RU-486 administration. Figure $6, A$ and $B$, shows a typical example, in which a DA-594-labeled transverse branch CF-b (red) formed VGluT2-positive terminals, some of which attached to a distal dendrite PCD-a of a neighboring PC (arrowheads). This PCD-a, however, was innervated by many terminals of a DA-594-unlabeled ascending branch CF-a (green or light blue), thus representing multiple innervation. In general, such ectopic terminals of transverse CF branches were few in number and intermingled with those of main ascending CFs. In parasag- 
A

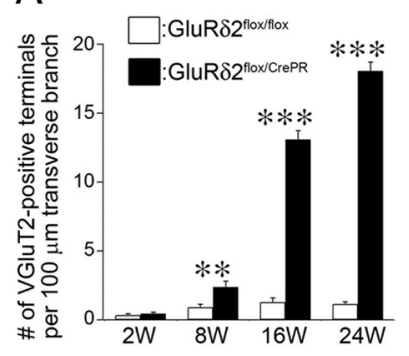

C
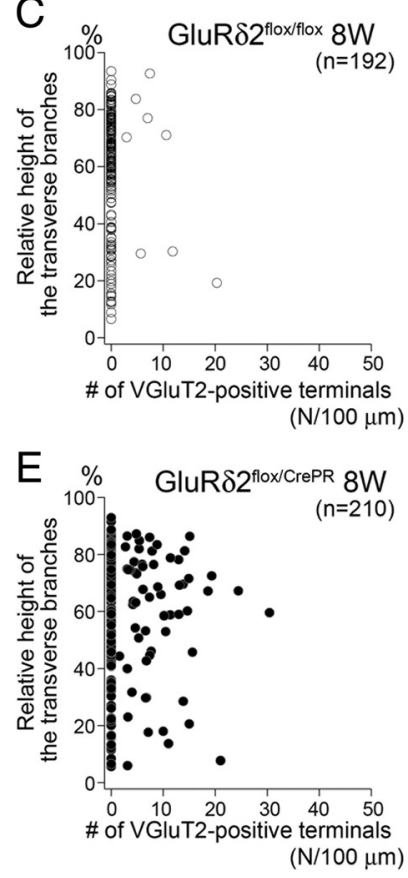

B

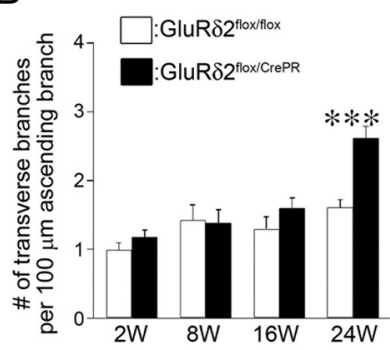

$\mathrm{D}$
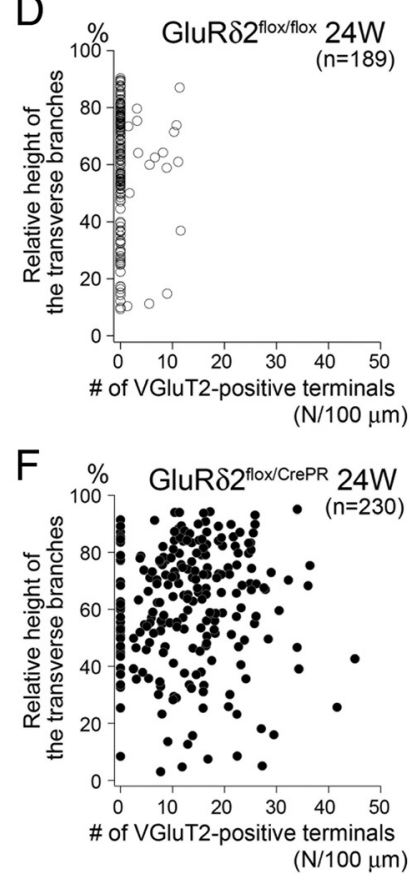

Figure 5. Progressive terminal differentiation in transverse $C F$ branches in a superficial half of the molecular layer after induction of GluR $\delta 2$ ablation. $\boldsymbol{A}$, The mean number of VGluT2positive terminals per $100 \mu \mathrm{m}$ of transverse branches in GluR $\delta 2^{\text {flox/flox }}$ (white bars) and GluR $\delta 2^{\text {flox/CrePR }}$ mice (black bars). Scores are $0.34 \pm 0.10$ ( $n=45$ transverse branches), $0.91 \pm 0.23(n=39), 1.29 \pm 0.30(n=35)$, and $1.14 \pm 0.16(n=51)$ in GluR $\delta 2^{\text {flox/flox }}$ mice, and $0.44 \pm 0.12(n=52), 2.37 \pm 0.43(n=38), 13.1 \pm 0.63(n=41)$, and $18.1 \pm 0.64(n=$ 68 ) in GluR $\delta 2^{\text {flox/CrePR }}$ mice at 2, 8,16 , and 24 weeks, respectively (mean \pm SEM; $p=0.67$ at 2 weeks, 0.0066 at 8 week, $p<0.00001$ at 16 and 24 weeks, $U$ test). $\boldsymbol{B}$, The mean number of transverse $\mathrm{CF}$ branches emitting from $100 \mu \mathrm{m}$ of ascending $\mathrm{CF}$ branches in GluR $\delta 2^{\text {floxfllox }}$ (white bars) and GluR $\delta 2^{\text {flox/CrePR }}$ mice (black bars). Scores are $0.98 \pm 0.10$ ( $n=51$ ascending branches), $1.43 \pm 0.22(n=48), 1.30 \pm 0.18(n=42)$, and $1.61 \pm 0.11(n=51)$ in GluR $\delta 2^{\text {flox/flox }}$ mice, and $1.18 \pm 0.10(n=56), 1.38 \pm 0.19(n=61), 1.60 \pm 0.15(n=40)$, and $2.61 \pm 0.17(n=67)$ in GluR $\delta 2^{\text {flox/CrePR }}$ mice at $2,8,16$, and 24 weeks, respectively (mean \pm SEM; $p=0.13,0.80$, and 0.07 at 2, 8 , and 16 weeks, respectively; $p<0.00001$ at 24 weeks, $U$ test). Error bars indicate SEM. ${ }^{* *} p<0.01,{ }^{* * *} p<0.001$. $C-F$, Scatterplots of the number of VGluT2-positive terminals per $100 \mu \mathrm{m}$ of transverse branches (horizontal axis) against its relative vertical height in the molecular layer (vertical axis) in $\operatorname{GluR} \delta 2^{\text {floxfllox }}(\boldsymbol{C}, \boldsymbol{D}$, white circles) and GluR $\delta 2^{\text {flox/crePR }}(\boldsymbol{E}, \boldsymbol{F}$, black circles) mice at 8 weeks $(\boldsymbol{C}, \boldsymbol{E})$ and 24 weeks $(\boldsymbol{D}, \boldsymbol{F})$ after RU administration.

ittal sections, multiple innervation by transverse branches appeared as abrupt emergence of isolated DA-594-labeled dots (Fig. $6 C, D, C F-b$, arrowheads) among most other terminals unlabeled with DA-594 (CF-a). Multiple CF innervation was further confirmed in horizontal cerebellar sections by double-labeling immunoelectron microscopy for VGluT2 (metal particles) and BDA (diffuse DAB precipitates) in mutant mice at 24 weeks after RU-486 administration. Figure $6 E-H$ show a distal dendrite studded with many free spines (Fig. $6 E$, arrowheads) (i.e., GluR $\delta 2$ ablated PC dendrite). This dendrite was mainly innervated by termi-

nals of a BDA-labeled/VGluT2-labeled ascending CF-a (Fig. 6E, $H$ ). In the adjacent sections, its distal portion was further innervated by a single small terminal of a BDA-unlabeled/VGluT2-labeled CF-b (Fig. $6 E 2, F)$. Because the trajectory of CF-b was perpendicular to that of the innervating dendrite, CF-b is likely a transverse branch originating from an ascending $\mathrm{CF}$ branch in the neighbor. Therefore, the ablation of GluR $\delta 2$ in adult PCs induces multiple innervation by aberrant wiring of transverse CF branches.

Together, these anatomical results demonstrate that the loss of GluR $\delta 2$ in adult PCs does permit CFs to extend distally and mediolaterally, and frequently causes multiple innervation to neighboring and remote PCs.

\section{CF phenotypes in GluR $\delta 2^{\text {flox/CrePR }}$ mice mimic those in global GluR $\delta 2$ knock-out}

The above results indicate that the two major anatomical phenotypes of global GluR $\delta 2$-knock-out mice are reproduced in GluR $\delta 2^{\text {flox/CrePR }}$ mice. In addition, we confirmed in the present study that multiple CF innervation caused by both ascending and transverse branches was also observed in global GluR $\delta 2$-knockout mice (supplemental Fig. S3, available at www.jneurosci.org as supplemental material).

As GluR $\delta 2^{\text {flox/CrePR }}$ mice at 24 weeks after RU-486 administration correspond to 30 weeks of age, we further compared CF phenotypes using the age-matched global GluR $\delta 2$-knock-out mice (supplemental Fig. S4, available at www.jneurosci.org as supplemental material). The number of VGluT2-positive terminals per $100 \mu \mathrm{m}$ of transverse branches was abnormally high in global GluR $\delta 2$-knock-out mice at 30 weeks of age (supplemental Fig. S4A, available at www.jneurosci.org as supplemental material), although the number was significantly lower than that in GluR $\delta 2{ }^{\text {flox } / C \text { rePR }}$ mice $(p<0.00001, U$ test $)$. However, the mean number of transverse branches per $100 \mu \mathrm{m}$ of ascending branches was comparable between age-matched GluR $\delta 2^{\text {flox/CrePR }}$ and global GluR $\delta 2$-knock-out mice (supplemental Fig. S4B, available at www.jneurosci.org as supplemental material) $(p=$ $0.4250, U$ test). When plotting the terminal number of a given transverse branch against its relative vertical height in the molecular layer, $69.6 \%$ (135 of 194) of transverse branches were distributed in the superficial one-half of the molecular layer in global GluR $\delta 2$-knock-out mice at 30 weeks of age (supplemental Fig. $\mathrm{S} 4 \mathrm{C}$, available at www.jneurosci.org as supplemental material), showing distribution plots quite similar to age-matched GluR $\delta 2^{\text {flox/CrePR }}$ mice (Fig. $5 F$ ). From these similarities, CF phenotypes by GluR $\delta 2$ ablation in adult PCs mimic those by global GluR $\delta 2$ knock-out in many respects.

\section{Multiple CF innervation increases progressively after RU administration}

These genotypic differences were further examined electrophysiologically. Using parasagittal cerebellar slices, PCs were recorded in the whole-cell configuration, and CFs were stimulated with a glass pipette placed in the granular layer near the recorded PCs (Konnerth et al., 1990; Hashimoto et al., 2001). Individual CF-EPSC was clearly discerned, because it was elicited in an all-or-none fashion, and showed prominent paired-pulse depression (Konnerth et al., 1990). To search CFs innervating a given PC, stimulation pipette was systematically moved by $\sim 20 \mu \mathrm{m}$ steps, and the stimulus intensity was gradually increased at each stimulation site (pulse width, $0.1 \mathrm{~ms}$; strength, 0-90 V) (Hashimoto and Kano, 2003).

In majority of PCs from control mice, a single large CF-EPSC was elicited in an all-or-none manner at each time point exam- 

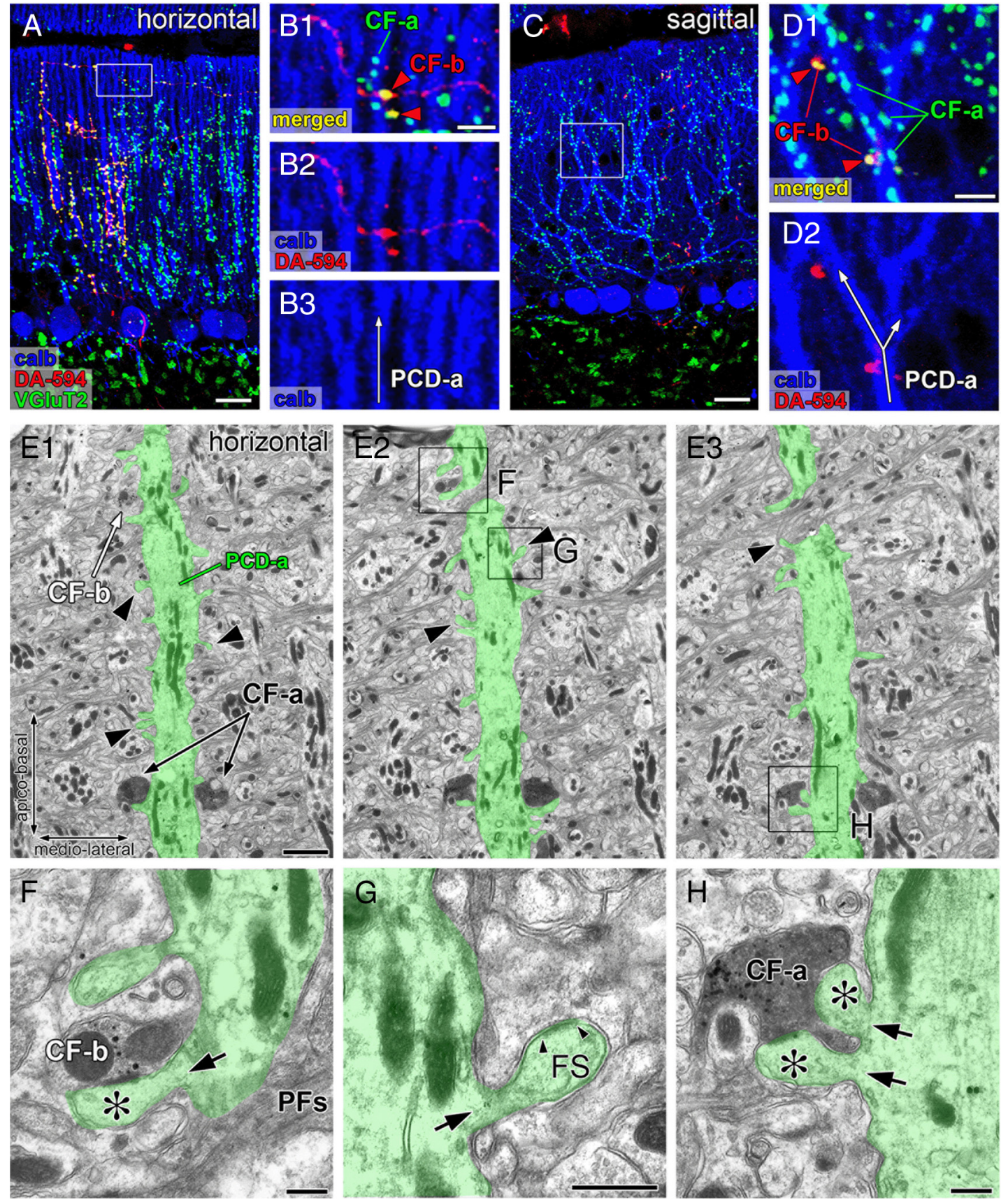

Figure 6. Multiple (F innervation caused by aberrant wiring of transverse (F branches. A-D, Triple fluorescent labeling for anterograde tracer DA-594 (red), calbindin (blue), and VGluT2 (green) in horizontal $(\boldsymbol{A}, \boldsymbol{B})$ and parasagittal $(\boldsymbol{C}, \boldsymbol{D})$ cerebellar sections of GluR $\delta 2^{\text {flox/CrePR }}$ mice at 16 weeks after RU-486 administration. The boxed regions in $\boldsymbol{A}$ and $\boldsymbol{C}$ are enlarged in $\boldsymbol{B}$ and $\boldsymbol{D}$, respectively. CF-a represents tracer-unlabeled CFs mainly innervating PC dendrites of interest (PCD-a), whereas (F-b represents tracer-labeled transverse branches additionally innervating the PCD-a (red arrowheads). $\boldsymbol{E}-\boldsymbol{H}$, Double-labeling serial electron microscopy for VGluT2 (metal particles) and anterograde tracer BDA (diffuse precipitates) in GluR $\delta 2^{\text {flox/(rePR }}$ mice at 24 weeks after RU-486 administration. The boxed regions in $\boldsymbol{E}_{2}$ and $\boldsymbol{E}_{3}$ are enlarged in $\boldsymbol{F}-\boldsymbol{H}$. PCD-a pseudocolored in green is a typical distal dendrite of $P(s$, but has numerous free spines (E, arrowheads; $\boldsymbol{G}, \mathbf{F S})$, thus indicating GluR $\delta 2$-ablated dendrite. Note that tracer-unlabeled CF-b $(\boldsymbol{F})$ and tracer-labeled $(F-a)(H)$ both innervate the PCD-a. The asterisks indicate spines contacting to terminals $C F$-a or $C F-b$. The small arrowheads in $\boldsymbol{G}$ indicate the edges of the postsynaptic density of free spine. The black arrows in $\boldsymbol{F}-\boldsymbol{H}$ indicate the neck of spines protruding from PCD-a. PFs, Parallel fiber axons. Scale bars: $A, C, 20 \mu \mathrm{m} ; B_{1}, D_{1}, 5 \mu \mathrm{m} ; \boldsymbol{E}, 2 \mu \mathrm{m} ; \boldsymbol{F}-\boldsymbol{H}, 500 \mathrm{~nm}$.

ined: $75.0 \%$ (27 of $36 \mathrm{PCs}$ ) at 2 weeks, $78.1 \%$ (25 of 32$)$ at 8 weeks, and $75.6 \%$ (28 of 37$)$ at 24 weeks after RU-486 administration (Fig. 7A-C, left traces; $D-F$, white bars), showing no significant differences between time points examined ( $p=0.41$ between 2 and 8 weeks, $p=0.90$ between 8 and 24 weeks, $\chi^{2}$ test). Thus, most PCs in control mice are innervated by single CFs. In mutant mice, the percentage of monoinnervated PCs was $73.0 \%$ (27 of 37 ) at 2 weeks, but decreased to $8.3 \%$ ( 3 of 36 ) at 8 weeks, and to
$2.7 \%$ ( 1 of 37 ) at 24 weeks (Fig. $7 A-C$, right traces; $D-F$, black bars). Between control and mutant mice, the frequency distribution of CF-EPSC step numbers showed no significant difference at 2 weeks ( $p=0.53, \chi^{2}$ test) but differed significantly at 8 and 24 weeks ( $p<0.0001$ for each comparison). Significant difference in the frequency distribution was also found in mutant mice between 2 and 8 weeks, and between 8 and 24 weeks $(p<0.0001$ for each comparison, $\chi^{2}$ test). Accordingly, the mean number of 
CF-EPSC steps was progressively increased in mutant PCs $(1.3 \pm 0.5,3.3 \pm$ 1.9 , and $8.2 \pm 3.6 \mathrm{CFs}$ at 2,8 , and 24 weeks, respectively), whereas it remained stable in control PCs $(1.3 \pm 0.4,1.3 \pm 0.5$, and $1.3 \pm 0.6 \mathrm{CFs}$ at 2,8 , and 24 weeks, respectively). These results indicate that multiple CF innervation progressively increased in mutant PCs.

Surplus CF-EPSCs with small amplitudes and slow kinetics emerge after GluR $\delta 2$ ablation

In both types of mice, CF-EPSCs in multiply innervated PCs were composed of a single main step having the largest amplitude and one or more surplus step(s) with much smaller amplitude (supplemental Fig. S5, available at www.jneurosci.org as supplemental material). The main CFEPSCs recorded from multiply innervated PCs and CF-EPSCs from monoinnervated PCs showed no significant differences in terms of the amplitude or kinetics (data not shown), therefore they were pooled together as "main CF-EPSCs," and their amplitudes and kinetics were compared with those of "surplus CF-EPSCs." These main CF-EPSCs displayed a clear paired-pulse depression to a similar extent in mutant and control mice at any time points examined (supplemental Fig. $\mathrm{S} 7 A$, available at www.jneurosci.org as supplemental material).

In control mice, both main and surplus CF-EPSCs were distributed as a single population with a peak around $0.5 \mathrm{~ms}$, and their amplitude and 10-90\% rise time were similar among various time points after RU-486 administration (Fig. $8 A, C, E$; supplemental Fig. S5 $A, C, E$, available at www.jneurosci.org as supplemental material). In mutant mice at 2 weeks, the distributions of amplitude and rise time of CF-EPSCs were comparable with those in control mice (Fig. 8 B; supplemental Fig. S5B, available at www.jneurosci. org as supplemental material). In mutant mice at 8 and 24 weeks, however, the rise time segregated into two distinct populations (Fig. $8 D, F$; supplemental Fig. S5D,F, available at www. jneurosci.org as supplemental material): The fast population $(<0.7 \mathrm{~ms}$, mean SD for CF-EPSCs from control mice) consisted mostly of the main CFs and centered around $0.5 \mathrm{~ms}$ (Fig. 8D,F; supplemental Fig. S5D, F, available at www.jneurosci.org as supplemental material). However, the slow population $(>0.7 \mathrm{~ms})$ consisted entirely of surplus CFs peaked around 2-3 ms (3.0 \pm $1.6 \mathrm{~ms}$ at 8 weeks; $n=75$ ) (Fig. $8 D$; supplemental Fig. S5D, available at www.jneurosci.org as supplemental material) (2.2 \pm $1.0 \mathrm{~ms}$ at 24 weeks; $n=246$ ) (Fig. $8 F$; supplemental Fig. S5F, available at www.jneurosci.org as supplemental material). Importantly, when those slow CF-EPSCs were omitted, the frequency distribution of fast CF-EPSCs was comparable between control and mutant mice at each time point (Fig. $8 G-I$ ), indicating that the CF input generating slow EPSCs was selectively recruited to mutant PCs. Surplus slow CF-EPSCs were also increased in am- plitude between 8 and 24 weeks $(19.7 \pm 14.7 \mathrm{pA}, n=69 ; 61.0 \pm$ $86.5 \mathrm{pA}, n=259$; mean \pm SD at 8 and 24 weeks, respectively; $p<$ $0.0001, U$ test) (supplemental Fig. S6, available at www.jneurosci. org as supplemental material). At 24 weeks, in addition to slow CF-EPSCs with small amplitude, those with large amplitude ( $>200$ pA) were occasionally observed (supplemental Fig. S6B, available at www.jneurosci.org as supplemental material). At each time point, there was no significant correlation between the rise time and amplitude of slow CF-EPSCs [Pearson's coefficients $\left(r^{2}\right)=0.04$ and 0.03 at 8 and 24 weeks, respectively] (supplemental Fig. S6, available at www.jneurosci.org as supplemental material).

In parallel with the increase of surplus slow CF-EPSC, the $10-90 \%$ rise time and decay time constant of the main CF-EPSCs became slower. At 2 weeks, the $10-90 \%$ rise time of the main $\mathrm{CF}$ from mutant mice was similar to that from control mice $(0.4 \pm$ $0.1 \mathrm{~ms}, n=30 ; 0.4 \pm 0.1 \mathrm{~ms}, n=27$; mean $\pm \mathrm{SD}$ from control and mutant mice, respectively; $p=0.71, U$ test) (Fig. $8 A, B$; supplemental Figs. S5 $A, B, \mathrm{~S} 7 B$, available at www.jneurosci.org as supplemental material), and 8 weeks $(0.5 \pm 0.1 \mathrm{~ms}, n=31 ; 0.5 \pm$ $0.1 \mathrm{~ms}, n=31$; from control and mutant mice, respectively; $p=$ 0.71 ) (Fig. $8 C, D$; supplemental Figs. $\mathrm{S} 5 C, D, \mathrm{~S} 7 B$, available at 
A

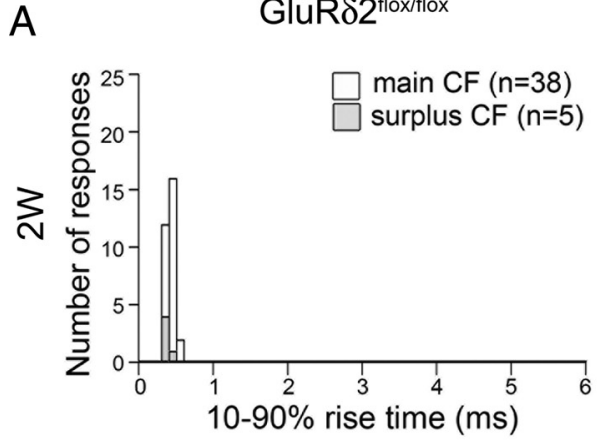

C

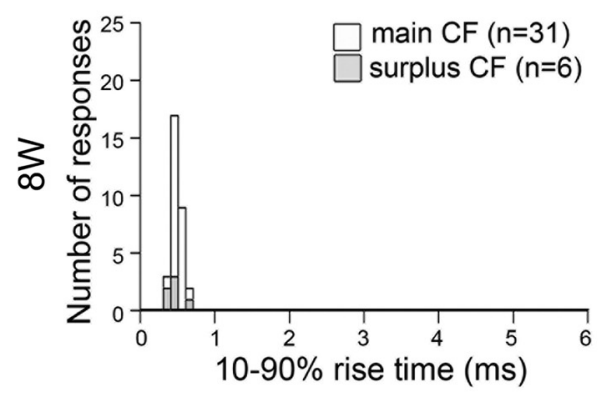

E

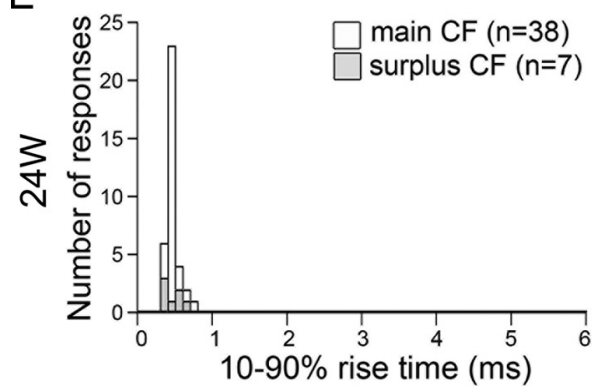

B

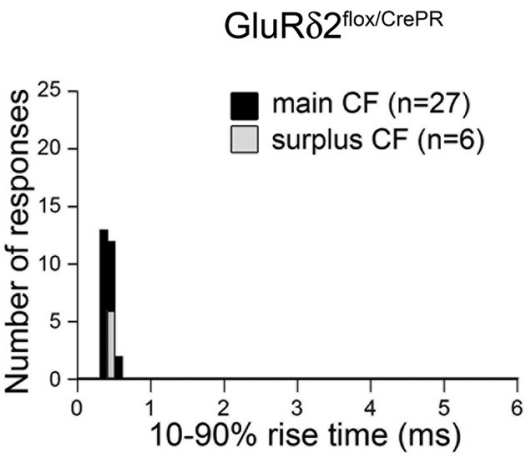

D

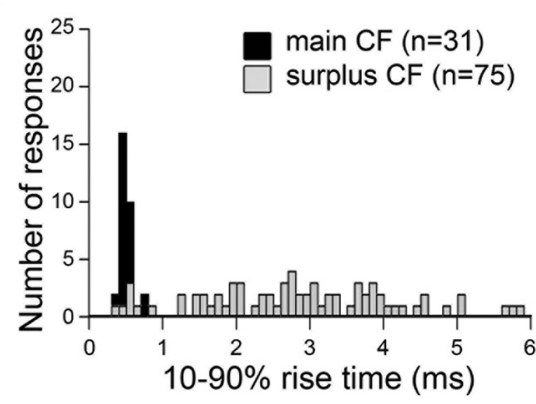

$\mathrm{F}$

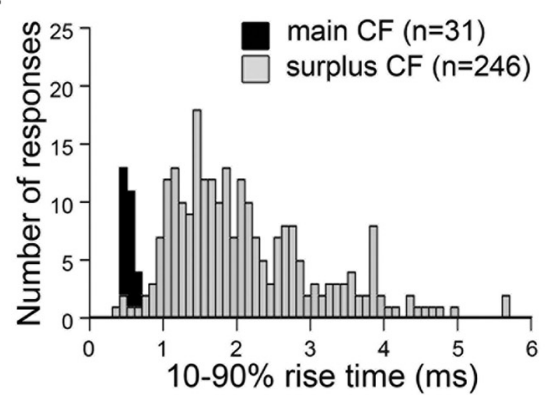

G

Fast kinetics only

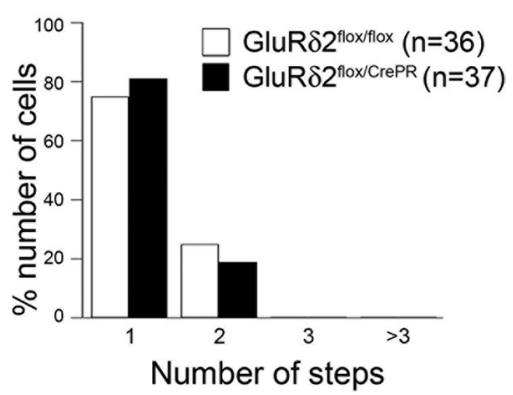

$\mathrm{H}$

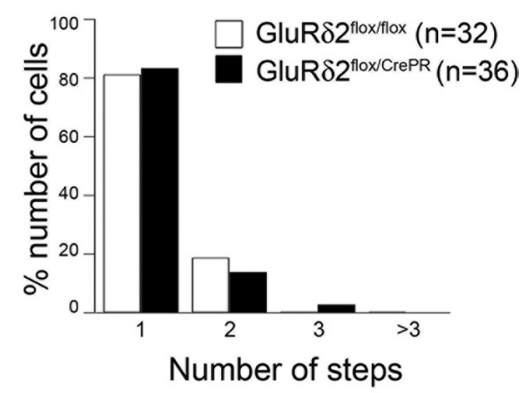

I

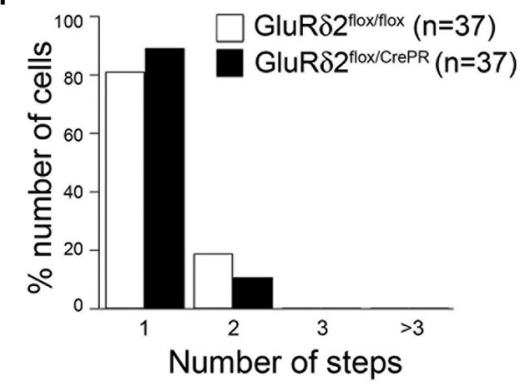

Figure 8. CFs with slow rise time increase after induction of GluR $\delta 2$ ablation. $\boldsymbol{A}-\boldsymbol{F}$, Frequency histograms showing the number of the $10-90 \%$ rise time of CF-EPSCs. At 8 and 24 weeks, $C F-E P S C S$ are segregated into fast and slow populations in GluR $\delta 2^{\text {flox/CrePR }}$ mice. Rise times of main $(\boldsymbol{A}, \boldsymbol{C}, \boldsymbol{E}$, white bars; $\boldsymbol{B}, \boldsymbol{D}, \boldsymbol{F}$, black bars) and surplus $(\boldsymbol{A}-\boldsymbol{F}$, gray bars) $\mathbf{C F}$ are overlaid. $\mathbf{G}-\boldsymbol{I}$, The frequency distribution of the number of (F-EPSCs with fast rise time only $(<0.7 \mathrm{~ms})$. Note no apparent differences between GluR $\delta 2^{\text {flox/flox }}$ (white bars) and GluR $\delta 2^{\text {flox/CrePR }}$ (black bars) PCs.

www.jneurosci.org as supplemental material). However, it was significantly slower in mutant mice than in control mice at 24 weeks $(0.5 \pm 0.1 \mathrm{~ms}, n=38 ; 0.6 \pm 0.2 \mathrm{~ms}, n=33$; from control and mutant mice, respectively; $p<0.001$ ) (Fig. $8 E, F$; supplemental Figs. S5 E, F, S7B, available at www.jneurosci.org as supplemental material). The decay time constant of the mutant main CF was similar to that of control at 2 weeks $(5.6 \pm 1.6 \mathrm{~ms}, n=30$; $6.1 \pm 1.4 \mathrm{~ms}, n=28$; mean \pm SD from control and mutant mice, respectively; $p=0.25, U$ test); however, it became significantly slower than that of control one thereafter $(5.5 \pm 1.1 \mathrm{~ms}, n=29$; $7.4 \pm 2.3 \mathrm{~ms}, n=31$; at 8 weeks, from control and mutant mice, respectively; $4.8 \pm 1.1 \mathrm{~ms}, n=29 ; 6.8 \pm 2.3 \mathrm{~ms}, n=32$; at 24 weeks, from control and mutant mice, respectively; $p<0.0001$ for each comparison) (supplemental Fig. S7C, available at www. jneurosci.org as supplemental material).

The slow kinetics of CF-EPSCs might be attributable to the distal extension of CF territory (Hashimoto et al., 2001; Uemura et al., 2007); however, EPSC waveforms can also be affected by other factors, including the passive membrane properties and dendritic arborization (Hashimoto et al., 2001; Roth and Hausser, 2001). Therefore, we next examined the passive membrane properties of PCs. Both time constants for the fast $(\tau 1)$ and slow $(\tau 2)$ components were not significantly different between control and mutant PCs at any time points examined (supplemental Table S1, available at www.jneurosci.org as supplemental material). Then we calculated several parameters representing passive membrane properties and found that there was no significant difference between the two strains at 2 and 8 weeks. However, in mutant mice at 24 weeks, the lumped dendritic capacitance (C2) became smaller, and lumped resistance (R3) became larger than control mice (supplemental Table S1, available at www.jneurosci.org as supplemental material). These results suggest that, at 24 weeks, the average total membrane area of the mutant PC dendrites is considerably smaller than that of control. This is consistent with the morphological data that the thickness of the mutant molecular layer decreases progressively (Fig. $1 G$ ). Therefore, the slow rise and decay time constants in mutant PCs cannot be explained by the altered passive membrane properties. Together, these results collectively demonstrate that GluR $\delta 2$ ablation in adult PCs induces aberrant innervation of distal dendrites by both main and surplus CFs, which may lead to the generation of numerous slow EPSCs with small amplitude and the slowing of main CF-EPSC kinetics. 

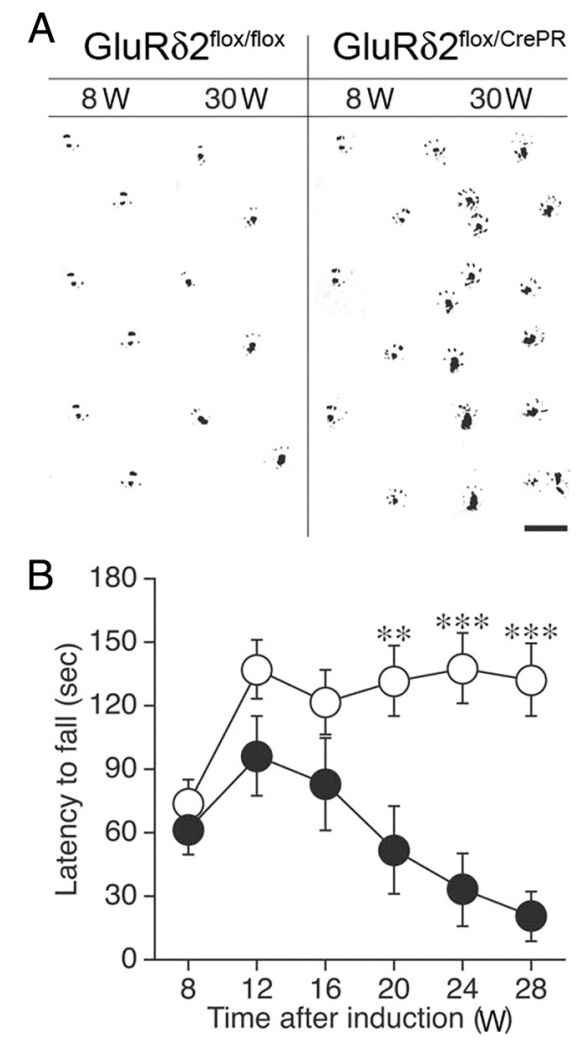

Figure 9. Motor discoordination. $\boldsymbol{A}$, Footprints of GluR $\delta 2^{\text {flox/flox }}$ and GluR $\delta 2^{\text {flox/CrePR }}$ mice at 8 and 30 weeks after RU-486 administration. Ink was applied to the hindpaws of the mice. Scale bar, $2 \mathrm{~cm}$. $\boldsymbol{B}$, The rotating rod test. Rotarod performance of GluR $\delta 2^{\text {flox/flox }}$ (open circles; $n=15$ ) and GluR $\delta 2^{\text {flox/CrePR }}$ (filled circles; $n=11$ ) mice. Retention time on the rotating rod at $15 \mathrm{rpm}$ was measured. Data are expressed as mean \pm SEM. ${ }^{* *} p<0.01$, ${ }^{* * *} p<0.001$, Student's $t$ test.

\section{Motor discoordination progresses slowly after GluR $\delta 2$ ablation}

Finally, changes in motor performance were assessed (Fig. 9). When the footprint pattern was examined, mutant mice at 8 weeks after RU-486 administration showed no ataxic gait and could walk along a straight line. However, mutant mice at 30 weeks were unable to walk straight and took tottering steps (Fig. $9 A)$. Such motor discoordination was not observed in RU-486treated control mice even at 30 weeks.

To evaluate more quantitatively, we performed a rotating rod test to compare the retention time on the rotating rod at $15 \mathrm{rpm}$. Control and mutant mice performed similarly at 8 weeks after RU-486 administration (Fig. 9B). However, the retention time in mutant mice gradually decreased thereafter with statistical differences being first apparent at 16 weeks and further exacerbated thereafter (Student's $t$ test, $p<0.01$ at 16 weeks, and $p<0.001$ at 24 and 28 weeks). There was a significant difference between the two genotypes (ANOVA with repeated measures, genotype effect, $\left.F_{(1,24)}=12.0, p=0.002\right)$. Thus, motor discoordination is manifested slowly but progressively after RU-486 administration.

\section{Discussion}

Using a conditional mouse model of GluR $\delta 2$ ablation in adult PCs, we have demonstrated that GluR $\delta 2$ plays an essential role in maintaining the mode of CF innervation that has been established during normal cerebellar development.

\section{GluR $\delta 2$ suppresses distal extension and innervation by ascending CF branch}

In GluR $\delta 2^{\text {flox/CrePR }}$ mice, relative height of CF terminals in the molecular layer started to increase at 8 weeks after RU-486 administration and further progressed until 24 weeks, when numerous VGluT2-positive CF terminals were distributed along atrophied distal dendrites (Fig. 1G,H). In horizontal cerebellar sections, this change was reflected as extended ladders of ascending CF branches along straight dendritic bars (Fig. 4). Importantly, distal extension of ascending branches occurred selectively along GluR $\delta 2$-ablated dendrites (Fig. 2A-E), and VGluT2positive terminals were differentiated on them (Fig. 1E,F). Therefore, GluR $\delta 2$ suppresses aberrant distal extension and innervation by ascending CF branches in adult cerebellum.

This suppressive action to CF innervation should be an indirect role of GluR $\delta 2$. First, CF synapses in adult PCs lack GluR $\delta 2$ (Takayama et al., 1995, 1996; Landsend et al., 1997; Zhao et al., 1998). Second, spines on distal dendrites are innervated exclusively by PFs in adult wild-type animals (Palay and Chan-Palay, 1974; Napper and Harvey, 1988), and the loss of GluR $\delta 2$ generates free spines on distal dendrites (Ichikawa et al., 2002). Third, viral transfer of GluR $\delta 2$ to adult GluR $\delta 2$-knock-out mice rapidly restores PF synapse formation in transfected PCs (Kakegawa et al., 2008, 2009). These results suggest that the primary role of GluR $\delta 2$ is to control and consolidate the connectivity of PF-PC synapses, which then suppresses aberrant extension and innervation by CFs. The present finding eventually highlights that GluR $\delta 2$ actively fuels heterosynaptic competition in adult cerebellum and gives PFs a competitive advantage over CFs. This molecular function will underlie rapid reinnervation of PC spines by sprouting PFs after surgical lesion to PFs (Chen and Hillman, 1982) and may also account for proximal expansion of PF innervation after surgical denervation of CFs (Sotelo et al., 1975) or CF regression after activity blockade by TTX (Bravin et al., 1999; Morando et al., 2001; Cesa et al., 2003, 2007).

Then, the countermechanisms should be working in adult cerebellum to balance the heterosynaptic competition. In this regard, P/Q-type $\mathrm{Ca}^{2+}$ channel may be one of the likely candidates, because it exerts such action during cerebellar development (Miyazaki et al., 2004). Whatever the counter mechanisms, it will ensure rapid reinnervation of adult PCs by surviving CFs after subtotal lesion of the inferior olive (Rossi et al., 1991a,b).

\section{GluR $\delta 2$ suppresses aberrant mediolateral wiring by transverse CF branch}

GluR $\delta 2$ ablation also drastically changed transverse CF branches, i.e., aberrant mediolateral elongation and progressive terminal differentiation (Figs. 4, 5). Ectopic terminals on transverse branches contacted PC dendrites at variable distances from parental ascending branches (Fig. 4J-O). Because transverse branches in wild-type rodents rarely form synapses on PCs (Rossi et al., 1991a; Sugihara et al., 1999; Nishiyama et al., 2007), our finding indicates that transverse branches retain synapseforming ability, but this ability is potently suppressed by mechanisms, including GluR $\delta 2$. Because these aberrant transverse branches were preferentially distributed in the superficial molecular layer (Fig. 5E,F), where PF-PC synapses are the main synaptic constituent, and also because ectopic CF terminals did innervate distal dendrites of GluR $\delta 2$-ablated PCs (Figs. $1 F, 6$ ), the emergence of free spines on distal dendrites likely induce aberrant mediolateral and distal extension of CF innervation.

Mediolateral extension of CF wiring will have another impact on the cerebellar physiology. Longitudinal olivocerebellar micro- 
zones have been identified in the cerebellar cortex, based on high synchrony of complex spike activity (Llinás and Sasaki, 1989; Sasaki et al., 1989; Sugihara et al., 1993; Lang et al., 1999; Fukuda et al., 2001) and $\mathrm{Ca}^{2+}$ spikes (Ozden et al., 2008; Mukamel et al., 2009; Schultz et al., 2009). Each microzone is $\sim 500 \mu \mathrm{m}$ in width, stable across behavioral states, and has sharp boundary with the neighboring microzones (Mukamel et al., 2009). This synchrony is based on electrical coupling of nearby olivary neurons through dendrodendritic gap junction (Llinás et al., 1974; Sotelo et al., 1986; Angaut and Sotelo, 1989; de Zeeuw et al., 1990) and topographical projection from given subnuclei of the inferior olive to specific longitudinal cortical zones (Sugihara et al., 1999, 2001). Axons derived from single olivary neurons project rostrocaudally to a narrow band ( $8 \mu \mathrm{m}$ in width) within a single lobule or across multiple lobules, but do not project mediolaterally (Sugihara et al., 1999, 2001). Therefore, very frequent mediolateral wiring by transverse branches will broaden and even disrupt functional organization of the olivocerebellar microzone system in GluR $\delta 2$ ablated cerebellum. Considering that GluR 82 -deficient PCs produce abnormal oscillating action potentials at $\sim 10 \mathrm{~Hz}$ because of enhanced CF activities and are thought to relate to involuntary spontaneous eye movement with characteristic $10 \mathrm{~Hz}$ oscillation (Yoshida et al., 2004), the aberrant mediolateral wiring could be one such anatomical basis for anomalous oscillatory activities and severe motor deficits in this mutant.

\section{GluR $\delta 2$ is essential to maintain CF monoinnervation}

Aberrant distal extension and mediolateral wiring eventually produced an enormous number of surplus branches that innervated many PCs around the main target, leading to frequent occurrence of multiple innervation (Figs. 3, 6). This anatomical phenotype was in good agreement with electrophysiological data. The number of CF-EPSC steps in GluR $\delta 2^{\text {flox/CrePR }}$ mice at 2 weeks after RU-486 administration was comparable with that in GluR $\delta 2^{\text {flox/flox }}$ mice (Fig. $7 D$ ). However, the number of CF-EPSC steps was significantly increased at 8 weeks (Fig. $7 E$ ), and $\sim 90 \%$ of PCs exhibited more than four steps at 24 weeks (Fig. $7 F$ ). Most surplus CF-EPSCs had small amplitude and slow kinetics (Figs. 7, 8; supplemental Fig. S5, available at www.jneurosci.org as supplemental material). These surplus CF-EPSCs with slow kinetics increased in both number and amplitude, whereas those with fast kinetics were unchanged (Fig. 8G-I; supplemental Figs. S5, S6, available at www.jneurosci.org as supplemental material). Considering that CF-EPSCs are strongly attenuated and slowed by dendritic filtering (Hashimoto et al., 2001; Roth and Hausser, 2001), slow CF-EPSCs with small amplitude likely correspond to aberrant wiring formed by ascending and transverse CF branches onto distal dendrites.

In contrast to GluR $\delta 2^{\text {flox/CrePR }}$ mice, a substantial fraction of surplus CF-EPSCs in global GluR $\delta 2$-knock-out mice displays fast as well as slow kinetics (Hashimoto et al., 2001). It is during the second postnatal week that PF synapses are formed enormously onto spines of growing PC dendrites in wild-type rodents (Woodward et al., 1971; Sotelo, 1978; Takács and Hámori, 1994), and that free spines increase drastically in global GluR $\delta 2$-knockout mice (Kurihara et al., 1997). Furthermore, it is also during this period that a single "winner" CF translocates to PC dendrites (Hashimoto et al., 2009). Since PF synapse activity is required to eliminate surplus CFs in normal cerebellar development (Bravin et al., 1995; Kakizawa et al., 2000), severe impairment during the period of active PF-PC synaptogenesis in global GluR $\delta 2$-knockout mice may allow surplus CFs with fast kinetics to survive into adulthood. Furthermore, free spines generated on growing PC dendrites might help surplus CFs to translocate from soma to proximal dendrites. By contrast, the elimination of surplus CFs and dendritic translocation of a single winner CF have completed well before the onset of GluR $\delta 2$ ablation in GluR $\delta 2^{\text {flox/CrePR }}$ mice. Therefore, unoccupied postsynaptic substrates are only available at distal dendrites in GluR $\delta 2^{\text {flox/CrePR }}$ mice, resulting in more purely distal type of multiple innervation than global GluR $\delta 2$ knock-out mice. Considering that the density of VGluT2positive terminals on transverse branches was significantly higher in GluR $\delta 2^{\text {flox/CrePR }}$ mice than global GluR $\delta 2$-knock-out mice (supplemental Fig. S4A, available at www.jneurosci.org as supplemental material), some compensatory mechanisms might work less in adulthood than during development.

\section{Temporal relationship of molecular, synaptic, and behavioral deficits}

Together with our previous study using GluR $\delta 2^{\text {flox/CrePR }}$ mice (Takeuchi et al., 2005), temporal relationships of molecular ablation, synaptic wiring abnormality, and behavioral deficit can be discussed. After RU-486 administration, the percentage of PCs expressing GluR $\delta 2$ mRNA was reduced to one-half level at 2 weeks and $20 \%$ at 4 weeks. Cerebellar contents of GluR $\delta 2$ protein were reduced to one-half level at 4 weeks, $21 \%$ at 8 weeks, and $<10 \%$ by 24 weeks (Takeuchi et al., 2005). Considering that RU486 was only administered at 2 consecutive days during P42-P45, this protracted time course should represent high stability of GluR $\delta 2$ mRNA and protein rather than low efficiency of gene recombination.

Synaptic wiring abnormalities, including mismatched PF synapses, free spines, extended CF territory, and multiple CF innervation, all became evident by 8 weeks after RU-486 administration, when cerebellar GluR $\delta 2$ contents were reduced to $21 \%$ of the control level. The abnormalities of PF-PC synapses correlated inversely with synaptic GluR $\delta 2$ protein densities (Takeuchi et al., 2005) and the aberrant CF innervation occurred against GluR $\delta 2$-ablated PC dendrites. These results indicate that defects of synaptic wiring proceed in a manner highly sensitive to GluR $\delta 2$ loss. In comparison, motor discoordination was not apparent at 8 weeks and gradually deteriorated thereafter (Fig. 9). Considering severe abnormalities in synaptic wiring at 16-24 weeks after RU-486 administration, our findings suggest that animals come to manifest cerebellar symptoms and disorders after considerable accumulation of wiring defects.

\section{References}

Angaut P, Sotelo C (1989) Synaptology of the cerebello-olivary pathway. Double labelling with anterograde axonal tracing and GABA immunocytochemistry in the rat. Brain Res 479:361-365.

Araki K, Meguro H, Kushiya E, Takayama C, Inoue Y, Mishina M (1993) Selective expression of the glutamate receptor channel delta 2 subunit in cerebellar Purkinje cells. Biochem Biophys Res Commun 197:1267-1276.

Bravin M, Rossi F, Strata P (1995) Different climbing fibres innervate separate dendritic regions of the same Purkinje cell in hypogranular cerebellum. J Comp Neurol 357:395-407.

Bravin M, Morando L, Vercelli A, Rossi F, Strata P (1999) Control of spine formation by electrical activity in the adult rat cerebellum. Proc Natl Acad Sci U S A 96:1704-1709.

Cesa R, Morando L, Strata P (2003) Glutamate receptor $\delta 2$ subunit in activity-dependent heterologous synaptic competition. J Neurosci 23:2363-2370.

Cesa R, Morando L, Strata P (2005) Purkinje cell spinogenesis during architectural rewiring in the mature cerebellum. Eur J Neurosci 22:579-586.

Cesa R, Scelfo B, Strata P (2007) Activity-dependent presynaptic and postsynaptic structural plasticity in the mature cerebellum. J Neurosci 27:4603-4611.

Chen S, Hillman DE (1982) Plasticity of the parallel fiber-Purkinje cell syn- 
apse by spine takeover and new synapse formation in the adult rat. Brain Res 240:205-220.

Crepel F (1982) Regression of functional synapses in the immature mammalian cerebellum. Trends Neurosci 5:266-269.

de Zeeuw CI, Holstege JC, Ruigrok TJ, Voogd J (1990) Mesodiencephalic and cerebellar terminals terminate upon the same dendritic spines in the glomeruli of the cat and rat inferior olive: an ultrastructural study using a combination of $\left[{ }^{3} \mathrm{H}\right]$ leucine and wheat germ agglutinin coupled horseradish peroxidase anterograde tracing. Neuroscience 34:645-655.

Edwards FA, Konnerth A, Sakmann B, Takahashi T (1989) A thin slice preparation for patch clamp recordings from neurones of the mammalian central nervous system. Pflugers Arch 414:600-612.

Fukuda M, Yamamoto T, Llinás R (2001) The isochronic band hypothesis and climbing fibre regulation of motricity: an experimental study. Eur J Neurosci 13:315-326.

Guastavino JM, Sotelo C, Damez-Kinselle I (1990) Hot-foot murine mutation: behavioral effects and neuroanatomical alterations. Brain Res 523: 199-210.

Hashimoto K, Kano M (2003) Functional differentiation of multiple climbing fiber inputs during synapse elimination in the developing cerebellum. Neuron 38:785-796.

Hashimoto K, Ichikawa R, Takechi H, Inoue Y, Aiba A, Sakimura K, Mishina M, Hashikawa T, Konnerth A, Watanabe M, Kano M (2001) Roles of glutamate receptor $\delta 2$ subunit (GluR $\delta 2)$ and metabotropic glutamate receptor subtype 1 (mGluR1) in climbing fiber synapse elimination during postnatal cerebellar development. J Neurosci 21:9701-9712.

Hashimoto K, Ichikawa R, Kitamura K, Watanabe M, Kano M (2009) Translocation of a "winner" climbing fiber to the Purkinje cell dendrite and subsequent elimination of "losers" from the soma in developing cerebellum. Neuron 63:106-118.

Hirai H, Pang Z, Bao D, Miyazaki T, Li L, Miura E, Parris J, Rong Y, Watanabe M, Yuzaki M, Morgan JI (2005) Cbln1 is essential for synaptic integrity and plasticity in the cerebellum. Nat Neurosci 8:1534-1541.

Ichikawa R, Miyazaki T, Kano M, Hashikawa T, Tatsumi H, Sakimura K, Mishina M, Inoue Y, Watanabe M (2002) Distal extension of climbing fiber territory and multiple innervation caused by aberrant wiring to adjacent spiny branchlets in cerebellar Purkinje cells lacking glutamate receptor $\delta 2$. J Neurosci 22:8487-8503.

Kakegawa W, Miyazaki T, Emi K, Matsuda K, Kohda K, Motohashi J, Mishina M, Kawahara S, Watanabe M, Yuzaki M (2008) Differential regulation of synaptic plasticity and cerebellar motor learning by the C-terminal PDZ-binding motif of GluR $\delta 2$. J Neurosci 28:1460-1468.

Kakegawa W, Miyazaki T, Kohda K, Matsuda K, Emi K, Motohashi J, Watanabe M, Yuzaki M (2009) The N-terminal domain of GluD2 (GluR $\delta 2)$ recruits presynaptic terminals and regulates synaptogenesis in the cerebellum in vivo. J Neurosci 29:5738-5748.

Kakizawa S, Yamasaki M, Watanabe M, Kano M (2000) Critical period for activity-dependent synapse elimination in developing cerebellum. J Neurosci 20:4954-4961.

Kano M, Hashimoto K, Chen C, Abeliovich A, Aiba A, Kurihara H, Watanabe M, Inoue Y, Tonegawa S (1995) Impaired synapse elimination during cerebellar development in PKC gamma mutant mice. Cell 83:1223-1231.

Kano M, Hashimoto K, Kurihara H, Watanabe M, Inoue Y, Aiba A, Tonegawa S (1997) Persistent multiple climbing fiber innervation of cerebellar Purkinje cells in mice lacking mGluR1. Neuron 18:71-79.

Kano M, Hashimoto K, Watanabe M, Kurihara H, Offermanns S, Jiang H, Wu Y, Jun K, Shin HS, Inoue Y, Simon MI, Wu D (1998) Phospholipase C $\beta 4$ is specifically involved in climbing fiber synapse elimination in the developing cerebellum. Proc Natl Acad Sci U S A 95:15724-15729.

Kashiwabuchi N, Ikeda K, Araki K, Hirano T, Shibuki K, Takayama C, Inoue Y, Kutsuwada T, Yagi T, Kang Y, Aizawa S, Mishina M (1995) Impairment of motor coordination, Purkinje cell synapse formation, and cerebellar long-term depression in GluR $\delta 2$ mutant mice. Cell 81:245-252.

Konnerth A, Llano I, Armstrong CM (1990) Synaptic currents in cerebellar Purkinje cells. Proc Natl Acad Sci U S A 87:2662-2665.

Kurihara H, Hashimoto K, Kano M, Takayama C, Sakimura K, Mishina M, Inoue Y, Watanabe M (1997) Impaired parallel fiber $\rightarrow$ Purkinje cell synapse stabilization during cerebellar development of mutant mice lacking the glutamate receptor $\delta 2$ subunit. J Neurosci 17:9613-9623.

Lalouette A, Lohof A, Sotelo C, Guénet J, Mariani J (2001) Neurobiological effects of a null mutation depend on genetic context: comparison between two hotfoot alleles of the delta-2 ionotropic glutamate receptor. Neuroscience 105:443-455.

Landsend AS, Amiry-Moghaddam M, Matsubara A, Bergersen L, Usami S, Wenthold RJ, Ottersen OP (1997) Differential localization of delta glutamate receptors in the rat cerebellum: coexpression with AMPA receptors in parallel fiber-spine synapses and absence from climbing fiber-spine synapses. J Neurosci 17:834-842.

Lang EJ, Sugihara I, Welsh JP, Llinás R (1999) Patterns of spontaneous Purkinje cell complex spike activity in the awake rat. J Neurosci 19:27282739.

Llano I, Marty A, Armstrong CM, Konnerth A (1991) Synaptic- and agonist-induced excitatory currents of Purkinje cells in rat cerebellar slices. J Physiol 434:183-213.

Llinás R, Sasaki K (1989) The functional organization of the olivo-cerebellar system as examined by multiple Purkinje cell recordings. Eur J Neurosci $1: 587-602$.

Llinás R, Baker R, Sotelo C (1974) Electrotonic coupling between neurons in cat inferior olive. J Neurophysiol 37:560-571.

Lomeli H, Sprengel R, Laurie DJ, Köhr G, Herb A, Seeburg PH, Wisden W (1993) The rat delta- 1 and delta-2 subunits extend the excitatory amino acid receptor family. FEBS Lett 315:318-322.

Mariani J, Crepel F, Mikoshiba K, Changeux JP, Sotelo C (1977) Anatomical, physiological and biochemical studies of the cerebellum from Reeler mutant mouse. Philos Trans R Soc Lond B Biol Sci 281:1-28.

Matsuda K, Miura E, Miyazaki T, Kakegawa W, Emi K, Narumi S, Fukazawa Y, Ito-Ishida A, Kondo T, Shigemoto R, Watanabe M, Yuzaki M (2010) Cbln1 is a ligand for an orphan glutamate receptor delta2, a bidirectional synapse organizer. Science 328:363-368.

Mishina M, Sakimura K (2007) Conditional gene targeting on the pure C57BL/6 genetic background. Neurosci Res 58:105-112.

Miura E, Fukaya M, Sato T, Sugihara K, Asano M, Yoshioka K, Watanabe M (2006) Expression and distribution of JNK/SAPK-associated scaffold protein JSAP1 in developing and adult mouse brain. J Neurochem 97:1431-1446.

Miyazaki T, Fukaya M, Shimizu H, Watanabe M (2003) Subtype switching of vesicular glutamate transporters at parallel fibre-Purkinje cell synapses in developing mouse cerebellum. Eur J Neurosci 17:2563-2572.

Miyazaki T, Hashimoto K, Shin HS, Kano M, Watanabe M (2004) P/Q-type $\mathrm{Ca}^{2+}$ channel $\alpha 1 \mathrm{~A}$ regulates synaptic competition on developing cerebellar Purkinje cells. J Neurosci 24:1734-1743.

Morando L, Cesa R, Rasetti R, Harvey R, Strata P (2001) Role of glutamate delta-2 receptors in activity-dependent competition between heterologous afferent fibers. Proc Natl Acad Sci U S A 98:9954-9959.

Mukamel EA, Nimmerjahn A, Schnitzer MJ (2009) Automated analysis of cellular signals from large-scale calcium imaging data. Neuron 63:747-760.

Napper RM, Harvey RJ (1988) Number of parallel fiber synapses on an individual Purkinje cell in the cerebellum of the rat. J Comp Neurol 274:168-177.

Nishiyama H, Fukaya M, Watanabe M, Linden DJ (2007) Axonal motility and its modulation by activity are branch-type specific in the intact adult cerebellum. Neuron 56:472-487.

Offermanns S, Hashimoto K, Watanabe M, Sun W, Kurihara H, Thompson RF, Inoue Y, Kano M, Simon MI (1997) Impaired motor coordination and persistent multiple climbing fiber innervation of cerebellar Purkinje cells in mice lacking G $\alpha$ q. Proc Natl Acad Sci U S A 94:14089-14094.

Ozden I, Lee HM, Sullivan MR, Wang SS (2008) Identification and clustering of event patterns from in vivo multiphoton optical recordings of neuronal ensembles. J Neurophysiol 100:495-503.

Palay S, Chan-Palay V (1974) Cerebellar cortex: cytology and organization, pp 63-69, 242-287. New York: Springer.

Rossi F, Wiklund L, van der Want JJ, Strata P (1991a) Reinnervation of cerebellar Purkinje cells by climbing fibres surviving a subtotal lesion of the inferior olive in the adult rat. I. Development of new collateral branches and terminal plexuses. J Comp Neurol 308:513-535.

Rossi F, van der Want JJ, Wiklund L, Strata P (1991b) Reinnervation of cerebellar Purkinje cells by climbing fibres surviving a subtotal lesion of the inferior olive in the adult rat. II. Synaptic organization on reinnervated Purkinje cells. J Comp Neurol 308:536-554.

Roth A, Häusser M (2001) Compartmental models of rat cerebellar Purkinje cells based on simultaneous somatic and dendritic patch-clamp recordings. J Physiol 535:445-472. 
Sasaki K, Bower JM, Llinás R (1989) Multiple Purkinje cell recording in rodent cerebellar cortex. Eur J Neurosci 1:572-586.

Schultz SR, Kitamura K, Post-Uiterweer A, Krupic J, Häusser M (2009) Spatial pattern coding of sensory information by climbing fiber-evoked calcium signals in networks of neighboring cerebellar Purkinje cells. J Neurosci 29:8005-8015.

Sotelo C (1978) Purkinje cell ontogeny: formation and maintenance of spines. Prog Brain Res 48:149-170.

Sotelo C, Hillman DE, Zamora AJ, Llinás R (1975) Climbing fiber deafferentation: its action on Purkinje cell dendritic spines. Brain Res 98:574-581.

Sotelo C, Gotow T, Wassef M (1986) Localization of glutamic-aciddecarboxylase-immunoreactive axon terminals in the inferior olive of the rat, with special emphasis on anatomical relations between GABAergic synapses and dendrodendritic gap junctions. J Comp Neurol 252:32-50.

Sugihara I, Lang EJ, Llinás R (1993) Uniform olivocerebellar conduction time underlies Purkinje cell complex spike synchronicity in the rat cerebellum. J Physiol 470:243-271.

Sugihara I, Wu H, Shinoda Y (1999) Morphology of single olivocerebellar axons labeled with biotinylated dextran amine in the rat. J Comp Neurol 414:131-148.

Sugihara I, Wu HS, Shinoda Y (2001) The entire trajectories of single olivocerebellar axons in the cerebellar cortex and their contribution to cerebellar compartmentalization. J Neurosci 21:7715-7723.

Takács J, Hámori J (1994) Developmental dynamics of Purkinje cells and dendritic spines in rat cerebellar cortex. J Neurosci Res 38:515-530.

Takayama C, Nakagawa S, Watanabe M, Mishina M, Inoue Y (1995) Lightand electron-microscopic localization of the glutamate receptor channel delta 2 subunit in the mouse Purkinje cell. Neurosci Lett 188:89-92.

Takayama C, Nakagawa S, Watanabe M, Mishina M, Inoue Y (1996) Developmental changes in expression and distribution of the glutamate receptor channel delta 2 subunit according to the Purkinje cell maturation. Brain Res Dev Brain Res 92:147-155.

Takeuchi T, Miyazaki T, Watanabe M, Mori H, Sakimura K, Mishina M (2005) Control of synaptic connection by glutamate receptor $\delta 2$ in the adult cerebellum. J Neurosci 25:2146-2156.

Torashima T, Iizuka A, Horiuchi H, Mitsumura K, Yamasaki M, Koyama C, Takayama K, Iino M, Watanabe M, Hirai H (2009) Rescue of abnormal phenotypes in delta2 glutamate receptor-deficient mice by the extracellular N-terminal and intracellular C-terminal domains of the delta2 glutamate receptor. Eur J Neurosci 30:355-365.

Tsujita M, Mori H, Watanabe M, Suzuki M, Miyazaki J, Mishina M (1999) Cerebellar granule cell-specific and inducible expression of Cre recombinase in the mouse. J Neurosci 19:10318-10323.

Uemura T, Mishina M (2008) The amino-terminal domain of glutamate receptor delta2 triggers presynaptic differentiation. Biochem Biophys Res Commun 377:1315-1319.

Uemura T, Kakizawa S, Yamasaki M, Sakimura K, Watanabe M, Iino M, Mishina M (2007) Regulation of long-term depression and climbing fiber territory by glutamate receptor $\delta 2$ at parallel fiber synapses through its C-terminal domain in cerebellar Purkinje cells. J Neurosci 27:12096-12108.

Uemura T, Lee SJ, Yasumura M, Takeuchi T, Yoshida T, Ra M, Taguchi R, Sakimura K, Mishina M (2010) Trans-synaptic interaction of GluR $\delta 2$ and Neurexin through Cbln1 mediates synapse formation in the cerebellum. Cell 141:1068-1079.

Watanabe M (2008) Molecular mechanisms governing competitive synaptic wiring in cerebellar Purkinje cells. Tohoku J Exp Med 214:175-190.

Woodward DJ, Hoffer BJ, Siggins GR, Bloom FE (1971) The ontogenetic development of synaptic junctions, synaptic activation and responsiveness to neurotransmitter substances in rat cerebellar Purkinje cells. Brain Res 34:73-97.

Yamasaki M, Hashimoto K, Kano M (2006) Miniature synaptic events elicited by presynaptic $\mathrm{Ca}^{2+}$ rise are selectively suppressed by cannabinoid receptor activation in cerebellar Purkinje cells. J Neurosci 26:86-95.

Yoshida T, Katoh A, Ohtsuki G, Mishina M, Hirano T (2004) Oscillating Purkinje neuron activity causing involuntary eye movement in a mutant mouse deficient in the glutamate receptor $\delta 2$ subunit. J Neurosci 24:2440-2448

Yuzaki M (2009) New (but old) molecules regulating synapse integrity and plasticity: Cbln1 and the delta2 glutamate receptor. Neuroscience 162: 633-643.

Zhao HM, Wenthold RJ, Petralia RS (1998) Glutamate receptor targeting to synaptic populations on Purkinje cells is developmentally regulated. J Neurosci 18:5517-5528. 